\title{
Geothermal Fluid Variation Recorded by Banded Ca-Carbonate Veins in a Fault-Related, Fissure Ridge-Type Travertine Depositional System (Iano, southern Tuscany, Italy)
}

\author{
Paola Francesca Matera $\left(D,{ }^{1}\right.$ Gennaro Ventruti ${ }^{D},{ }^{1}$ Martina Zucchi ${ }^{(D)},{ }^{1}$ Andrea Brogi $\left(\mathbb{D},{ }^{1,2}\right.$ \\ Enrico Capezzuoli $\mathbb{D}^{3}{ }^{3}$ Domenico Liotta $\mathbb{}^{1},{ }^{1,2}$ Tsai-Luen Yu, ${ }^{4,5}$ Chuan-Chou Shen $\mathbb{D}^{4,5}$ \\ Katharine W. Huntington $\oplus^{6},{ }^{6}$ László Rinyu, ${ }^{7}$ and Sándor Kele ${ }^{8}$ \\ ${ }^{1}$ Department of Earth and Geoenvironmental Sciences, University of Bari, Bari, Via Orabona 4, Italy \\ ${ }^{2} I G G-C N R$, Institute of Geosciences and Earth Resources, Pisa, Via Moruzzi 1, Italy \\ ${ }^{3}$ Department of Earth Sciences, University of Florence, Florence, Via La Pira 4, Italy \\ ${ }^{4}$ High-Precision Mass Spectrometry and Environment Change Laboratory (HISPEC), Department of Geosciences, \\ National Taiwan University, Taipei 10617, Taiwan \\ ${ }^{5}$ Research Center for Future Earth, National Taiwan University, Taipei 10617, Taiwan \\ ${ }^{6}$ Department of Earth and Space Sciences, University of Washington, Seattle, WA 98195, USA \\ ${ }^{7}$ Isotope Climatology and Environmental Research Centre (ICER), Institute for Nuclear Research (ATOMKI), Hungarian Academy \\ of Sciences, Bem tér 18/c, 4026 Debrecen, Hungary \\ ${ }^{8}$ Institute for Geological and Geochemical Research, Research Centre for Astronomy and Earth Sciences, MTA Centre for Excellence, \\ Budapest, Hungary
}

Correspondence should be addressed to Paola Francesca Matera; materapaola.f@gmail.com

Received 20 July 2020; Revised 28 October 2020; Accepted 16 November 2020; Published 30 January 2021

Academic Editor: Cinzia Federico

Copyright (c) 2021 Paola Francesca Matera et al. This is an open access article distributed under the Creative Commons Attribution License, which permits unrestricted use, distribution, and reproduction in any medium, provided the original work is properly cited.

Banded Ca-carbonate veins in travertine deposits are efficient recorders of the compositional fluctuations of geothermal fluids flowing (or flowed) from deep reservoirs up to the surface, within fault zones. In this view, these veins represent key tools for decoding those factors that influenced the geochemical variations. We have analyzed veins developed in fractures channeling geothermal fluids forming travertine deposits. The studied veins cut a fossil travertine fissure ridge, near the Larderello geothermal area (Iano area, southern Tuscany) where geothermal fluid circulation is favored by NE-trending strike-to-obliqueslip faults and their intersections with NW-trending normal ones. U-Th dating indicates that fluid circulation occurred from (at least) $172 \mathrm{ka}$ to $21 \mathrm{ka}$. In this time span, the geothermal fluid changed in composition, and the banded Ca-carbonate veins recorded these variations in terms of mineralogical and stable isotope composition and temperature $(T)$ of deposition. We also documented for the first time the occurrence of Mn-rich black tree-shaped structures within the veins. Mineralogy coupled with stable and clumped isotope measurements allows the reconstruction of some features (i.e., crystal texture, temperature, and $\mathrm{CO}_{2}$ origin) and the inference of the processes (i.e., $\mathrm{pH}, \mathrm{T}$, and $\mathrm{pCO}_{2}$ variations) that have controlled the fluid evolution through time. Multiple-stage and one-stage deposition processes have played an important role in modifying the stable isotope composition of banded Ca-carbonate veins; temperature coupled with $\mathrm{pCO}_{2}$ also influenced their mineralogical composition. Interpreted in the context of the tectonic setting, the data show that the NW-trending faults have mainly controlled travertine deposition. Their intersection with NE-trending faults, interpreted as transfer faults, highlights the important role of transfer zones in channeling the geothermal fluids. 


\section{Introduction}

Faults and associated fractures are discontinuities of the upper crust able to control the circulation of geothermal fluids, thus favoring combined convective-advective heat propagation processes [1]. If geothermal fluids are stored in carbonate reservoirs, or interact with carbonate rocks, fluid composition is enriched in $\mathrm{Ca}^{2+}$ and $\mathrm{CO}_{3}{ }^{-}$while the saline content depends on the amount of dissolved $\mathrm{CO}_{2}$, fluid temperature, and $\mathrm{pH}$ [2-8]. If fluids reach the surface through permeable faults and their damaged volumes, thermal springs develop [9], depositing masses of $\mathrm{CaCO}_{3}$ (i.e., travertine deposits; [5]) mainly due to the $\mathrm{CO}_{2}$ leakage $[5,8,10,11]$. In these settings, the rise of geothermal fluids and travertine deposition are assumed to be contemporaneous with the activity of faults channeling the fluids [3, 12-15]. Thus, travertine deposits can act as tectonic markers in geothermal areas [16-20] and potentially provide key geochronologic constraints since carbonate deposits can be dated using different radiometric methods [7, 13, 15, 21].

The interplay between fault activity and travertine deposition was addressed by several authors in the last decades [3, $16,18,19,22-25]$. Travertine fissure ridges [26] are considered the most useful deposits for neotectonic investigations in geothermal areas. A fissure ridge-type travertine deposit consists of a ridge made of bedded travertine, from gently to steeply dipping away from the apical part, where the central fissure is located, corresponding to the fault trace intersecting the substratum. From such a fissure, the geothermal fluids flow out, and travertine deposition takes place, growing the ridge.

The relationships among fluid flow, travertine deposits, and tectonic activity have been discussed by several authors, especially focusing on fissure ridges (e.g., [3, 12, 18, 19, 2731]). Variations in the chemistry and isotope composition of the travertine forming the ridge and, especially, of the banded Ca-carbonate veins (i.e., banded travertine in [22]) filling the fissure can be linked to different processes influencing hydrogeochemistry, including climate $[8,32]$, volcanism [33], fluid-rock interaction, and tectonics [3, 7, $34,35]$, with particular concern on the palaeoseismicity (cf. $[8,13,15])$. This attempt encounters several difficulties, because there are many parameters that influence the geochemical characteristics of this kind of carbonate deposit. In particular, the tectonic activity controls the permeability of the fault rocks and, as a consequence, the hydrothermal fluid pathways within the crust. Such tectonic effects likely exert stronger control than climatic effects on hydrothermal fluid property variations within hypogean conduits, such as faults and fractures. In order to constrain the possible impact of the tectonic activity on the geochemical and isotopic composition of the geothermal fluids, we analyzed banded Ca-carbonate veins formed in a late Pleistocene fissure ridge-type travertine depositional system cropping out nearby the Larderello geothermal area (southern Tuscany, Italy; [36]). This is an ideal region for this kind of study, since it records a long evolution of the geothermal fluid flow, veins, and related travertine deposits that are exposed in the area (Iano area, Figure 1) located in the shoulder of a broad Neo- gene structural depression (known as the Volterra Basin, [37, 38]). Here, late Quaternary tectonics gave rise to a shallow hydrothermal system and travertine deposition and still ensures active thermal springs. The analyzed veins formed during several episodes show different fabrics and colors suggesting compositional changes through time. We discuss the variation of the mineralogy (i.e., aragonite and calcite) and stable isotopic composition in relation with the tectonic activity. Furthermore, we document the occurrence of Mnrich black three-shaped structures forming some bands within the banded $\mathrm{Ca}$-carbonate veins. We interpret these observations as evidence of change in geothermal fluid properties, possibly induced by the tectonic activity, promoting a variation in the fluid-rock interaction.

\section{Geological Setting}

The study area is located in a sector of the inner Northern Apennines, about $20 \mathrm{~km}$ North of the Larderello geothermal area (Figure 1(b)) and in the eastern shoulder of a wide, NNW-SSE oriented Neogene structural depression (Volterra Basin, [37, 38]). The Northern Apennines originated from the convergence and collision (late Cretaceous-early Miocene) between the Adria promontory of the African plate and the European plate represented by the Sardinia-Corsica massif ([39], and references therein). This process gave rise to the stacking of several tectonic units deriving from different palaeogeographic domains [40]. From the top, these units are [41] (a) the Ligurian units, derived from the LigurianPiedmont Domain, and consisting of remnants of Jurassic oceanic crust and its late Jurassic-Cretaceous, mainly clayey and sedimentary cover; (b) the sub-Ligurian units (subLigurian domain), made up of Cretaceous-Oligocene turbidites; and (c) the Tuscan units forming a duplex system and composed of HP metamorphic and sedimentary units ranging from Palaeozoic to early Miocene in age [41-45]. After nappe stacking, an eastward migrating extension (e.g., [39, 46-53]) affected the inner Northern Apennines (i.e., northern Tyrrhenian Sea and Tuscany), since earlymiddle Miocene [48, 54-58]. Extensional tectonics thinned the previously overthickened lithosphere and continental crust, up to 50 and $20-25 \mathrm{~km}$, respectively [59]. This geological process was a consequence of a mainly eastward dipping normal fault system $[48,60-62]$ that produced (a) the lateral segmentation of the more competent levels within the previously stacked tectonic units [63], (b) the direct superimposition of the Ligurian units on the late Triassic evaporite and/or on the Palaeozoic phyllite, both representing regional detachment levels [61, 62], and (c) the development of bowl-shaped tectonic depressions where Miocene continental and marine sedimentation occurred $[60,61,64]$ and superimposed Pliocene-Pleistocene basins bounded by faults which dissected the previous extensional detachments [41, 46, 62, 65-68].

These Neogene-Quaternary basins, including the Volterra Basin, were filled by Pliocene-Quaternary marine and continental sediments [37, 52]. Their deposition was controlled by the activity of NNW-SSE-striking normal faults and coeval NE-trending transfer zones $[69,70]$, along which 


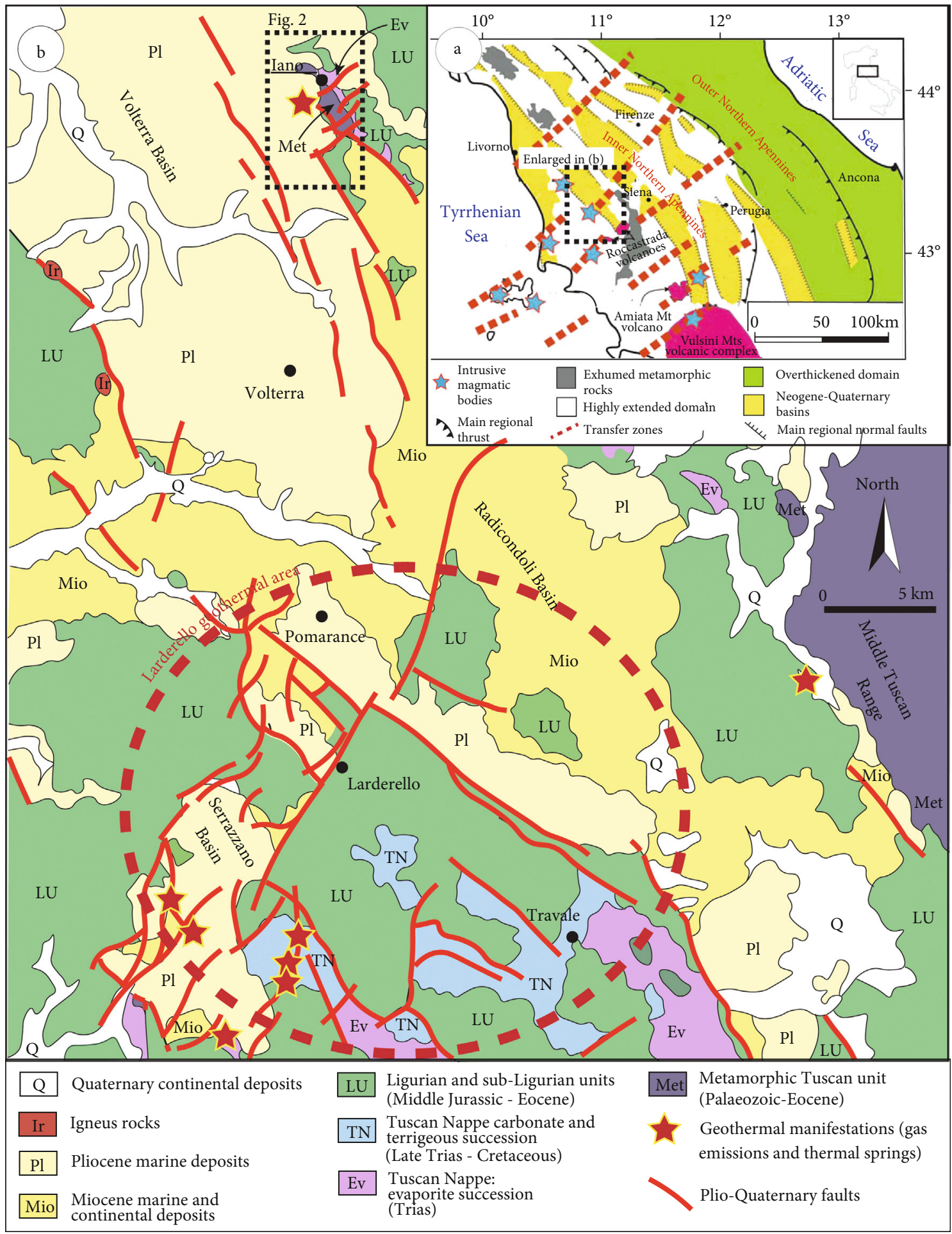

Figure 1: (a) Structural map of the Northern Apennines highlighting the main transfer zones from [19] and (b) geological map of the Larderello geothermal area and Volterra Basin. The study area is also indicated. Redrawn after Brogi et al.[134] and Liotta and Brogi [19].

most of the late Miocene-Pleistocene magmatic activity is concentrated $[24,68,71-75]$. Geothermal fluid circulation in the whole inner Northern Apennines also appears to be controlled by transfer zones [19, 75-78]. The Iano area is located within a transfer zone (Figure 1(b)) dissecting a NNW-SSE trending normal fault system that bounds the
Volterra Basin to the east. The interplay between the two fault systems (i.e., transfer and normal faults) gave rise to favorable conditions for hydrothermal circulation and thermal springs occurrence (Figure 2). Travertine deposits, some of which have been quarried, developed near the thermal springs. Deposition is still active in the surroundings of the 


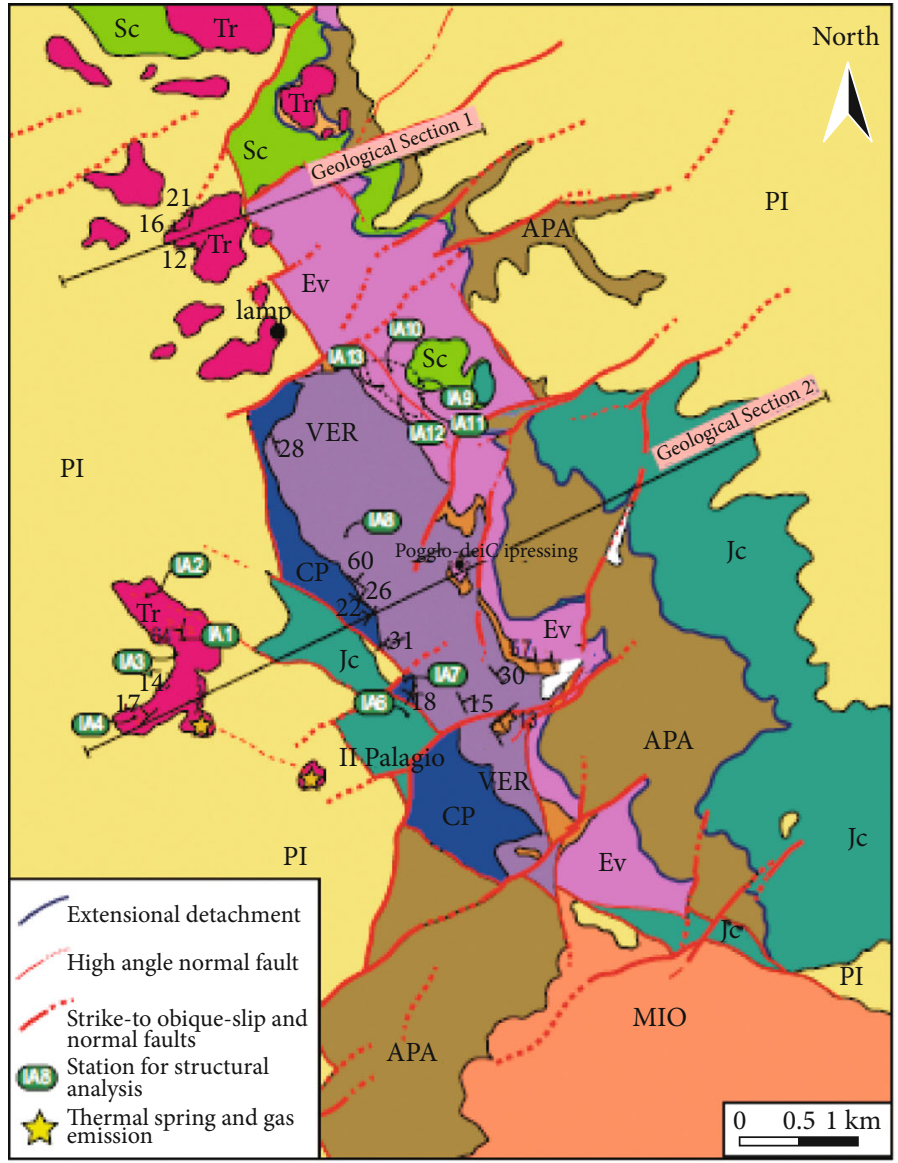

Quaternary deposits

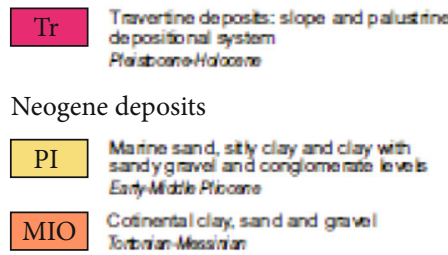

Ligurian unit

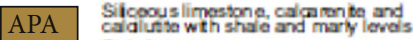
Enty Cotasosos

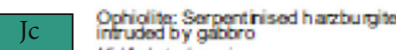
Midlol ato dinersic

Tuscan unit

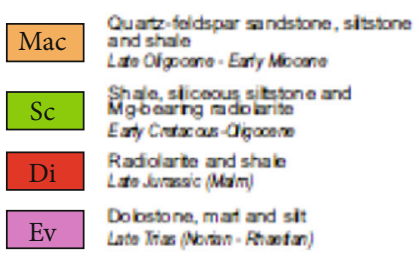

Monticiano-Roccastrada unit

TCC Chionto phyliso and motacationsto

Vervucano Girour. metasitstone, quattix

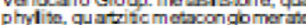
Entrit Lato Tis

Pahoroic Grours gurtetic metasandstone. metasilzane, phyise

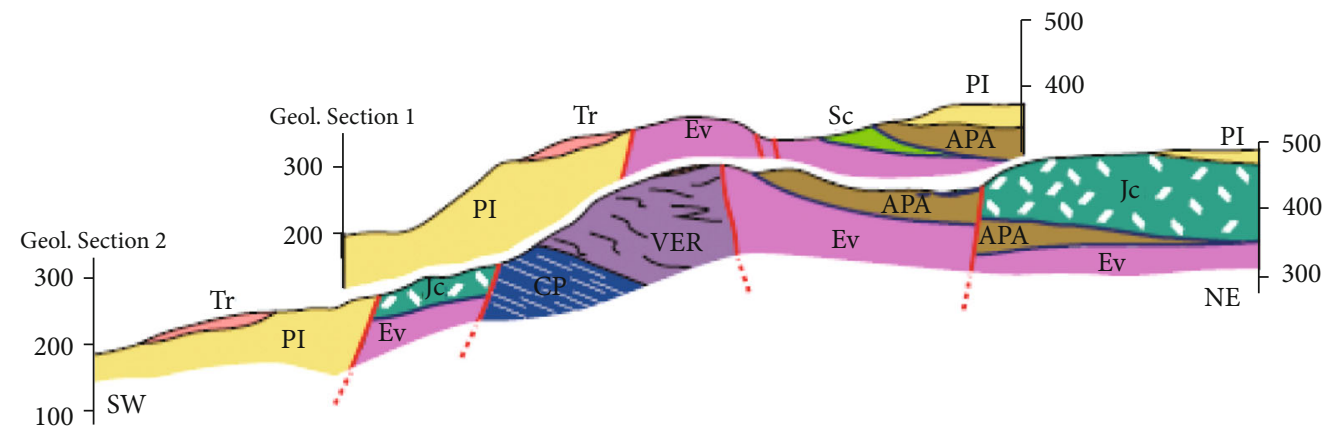

FIGURE 2: Geological map of the Iano area and related geological sections.

Iano village where low temperature thermal springs $\left(T=22^{\circ} \mathrm{C}\right)$ are still discharging $\mathrm{Ca}(\mathrm{Mg})-\mathrm{HCO}_{3}$ fluids with high content of $\mathrm{Sr}$ and $\mathrm{SO}_{4}[11]$.

The Iano area was investigated during $\mathrm{Hg}$ and coal mining exploration since eighteenth and nineteenth centuries, and detailed information about its geological setting can be found in Barberi [79] and Costantini et al. [80].

\section{Methods}

We conducted detailed description and analysis of the banded Ca-carbonate veins crossing travertine deposits, to investigate their (i) geometrical setting in relation to the main structures, (ii) mineralogy and textural features, (iii) stableand clumped isotopic compositions related to the fluid geochemistry and temperature, and (iv) depositional ages as inferred by U-Th geochronology.

3.1. Geometrical Setting, Mineralogy and Textural Features. A detailed study of travertine stratigraphic setting and its structural features was carried out applying the classical methods of sedimentary and structural geology. The collected data were interpreted in the context of the area's tectonic setting, which we have represented in a new geological map at $1: 10$ 000 scale (Figure 2). This map was produced via integration of preexisting geological maps (geological map of Tuscany $1: 10.000$ scale and geological map of [80]) and new field data, covering an area of about $11 \mathrm{~km}^{2}$. Structural and kinematic data were collected in favorable exposures through structural stations, as indicated in Figure 2. The attitude of 
banded Ca-carbonate veins was also analyzed and compared with the fault striking.

To visualize textural and mineralogical changes, a petrographic investigation of the samples was performed by polarized light optical microscopy on thin sections from several samples of banded Ca-carbonate veins using a ZeissAxioplane polarizing microscope. Based on this investigation, three key samples, labelled PAM1, PAM13 and ET3, were selected for SEM-EDS, X-ray powder diffraction, micro-Raman analyses, stable isotope measurements, and U-Th dating. Several aliquots of one sample (IA1) were selected for clumped isotope thermometry.

Scanning electron microscope (SEM) observations and microanalysis (EDS) of selected bands were performed at the Department of Earth and GeoEnvironmental Sciences (University of Bari), using a ZEISS EVO 50XVP instrument, coupled with energy dispersive X-ray Spectroscopy (EDS, Oxford-Link). Selected areas were observed on thin sections of samples PAM1 and PAM13 after graphite sputtercoating ( $30 \mathrm{~nm}$ thick). Elemental distributions of $\mathrm{Mn}$ were also mapped.

Mineralogical identification of PAM1 and PAM13 samples was determined by means of X-ray powder diffraction using an Empyrean, Malvern Panalytical Diffractometer at the Department of Earth and Geo-Environmental Sciences (University of Bari). X-ray powder diffractogram (XRPD) data were collected in the 6-80 $2 \theta$ range using $\mathrm{Ni}$-filtered $\mathrm{CuK} \alpha$ radiation obtained at $40 \mathrm{kV}$ and $40 \mathrm{~mA}$. For this purpose, polished sample fragments and randomly oriented powder mounts were used. The analysis of the powder XRPD patterns was carried out using Highscore Plus software. The lattice parameter determination was carried out by means of Rietveld refinement using the software BGMN [81]. In addition to XRPD analysis, confocal Raman microscopy was used for a more detailed mineralogical characterization. Micro-Raman spectra were recorded with a LabRAM HR Evolution Horiba spectrometer at the Department of Chemistry (University of Bari). This spectrometer is equipped with an Ultra-Low Frequency (ULF) notch filter and an electrically cooled CCD detector. Raman spectra were excited by a $\mathrm{He} / \mathrm{Ne}(\lambda=632.8 \mathrm{~nm})$ laser source using a $50 \times$ long working distance objective. The instrument was calibrated using the $520 \mathrm{~cm}^{-1}$ line of a Si wafer. Raman spectra were collected on polished thin section of PAM1 and PAM13 samples by using LabSpec6-Horiba software and reworked by using Origin software. Repeated acquisitions were accumulated in the $100-3800 \mathrm{~cm}^{-1}$ range to improve the signal-to-noise ratio. Micro-Raman spectra were recorded on different colored bands for each sample. Spectral scanning was also performed in the sample areas where black tree-shaped structures were clearly identified.

3.2. Vein Isotopic Composition and Geochronology. Stable carbon and oxygen isotope measurements were performed on single bands composing each vein (PAM1, PAM13, and ET3). Analyses on microdrilled powders were carried out at the Institute for Geological and Geochemical Research, Research Centre for Astronomy and Earth Sciences (Budapest, Hungary). Powdered sample analyses were carried out using the continuous flow technique with the $\mathrm{H}_{3} \mathrm{PO}_{4}$ digestion method [82]. ${ }^{13} \mathrm{C} /{ }^{12} \mathrm{C}$ and ${ }^{18} \mathrm{O} /{ }^{16} \mathrm{O}$ ratios were measured in $\mathrm{CO}_{2}$ gases using a Finnigan Thermo delta plus XP mass spectrometer equipped with an automated GasBench II. The results are expressed in $\delta$-notation $[\delta=(\mathrm{R} 1 / \mathrm{R} 2-1) \times$ 1000 , where $\mathrm{R} 1$ is the ${ }^{13} \mathrm{C} /{ }^{12} \mathrm{C}$ or ${ }^{18} \mathrm{O} /{ }^{16} \mathrm{O}$ ratio of the sample, and R2 is the corresponding ratio of the Vienna Pee Dee Belemnite (V-PDB) standard] in parts per thousand. Isotopic compositions are expressed in the standard $\delta$-notation in parts per thousand (\%o) relative to $\mathrm{V}-\mathrm{PDB}\left(\delta^{13} \mathrm{C}\right.$ and $\left.\delta^{18} \mathrm{O}\right)$ and Vienna Standard Mean Ocean Water (V-SMOW; $\delta^{18} \mathrm{O}$ ). Reproducibility was better than $\pm 0.1 \%$ for carbonate $\delta^{13} \mathrm{C}$ and $\delta^{18} \mathrm{O}$.

Clumped isotope thermometry [83-85] was applied to determine the precipitation temperature of carbonate minerals in order to reconstruct the palaeotemperature of the hydrothermal fluids channeled through the faults. The powdered sample (IA1) was analyzed at the University of Washington's IsoLab, Seattle, WA, USA, using the procedures of Burgener et al. [86]. For each replicate analysis, 6$8 \mathrm{mg}$ of carbonate powder was digested in a common acid bath at $90^{\circ} \mathrm{C}$, and the resulting sample $\mathrm{CO}_{2}$ was purified cryogenically using an automated system. Measurements were performed using a Thermo Scientific MAT 253 mass spectrometer with dual inlet configured to measure $\mathrm{m} / \mathrm{z} 44,45$, $46,47,48$, and 49. Data were corrected following Schauer et al. [87], using the ${ }^{17} \mathrm{O}$ interference correction parameters recommended by Brand et al. [88] as well as a pressure baseline correction [89] to calculate $\delta^{13} \mathrm{C}, \delta^{18} \mathrm{O}$, and $\Delta_{47} . \delta^{13} \mathrm{C}$ and $\delta^{18} \mathrm{O}$ values were referred to the V-PDB and V-SMOW scales using internal laboratory standards calibrated against international standards NBS-18 and NBS-19 (International Atomic Energy Agency, Vienna, Austria) and LSVEC (National Institute of Standards and Technology, Gaithersburg, MD, USA). A calcium carbonate reference material (ETH 1-4, [90]) or in-house standards were analyzed every 4 unknown samples. $\Delta_{47}$ values were referred to the carbon dioxide equilibrium scale (CDES) using $\mathrm{CO}_{2}$ heated to $1000^{\circ} \mathrm{C}$ and $\mathrm{CO}_{2}$ equilibrated with water at $60^{\circ} \mathrm{C}$ and $4^{\circ} \mathrm{C}$. Palaeotemperatures were calculated from the sample average corrected mean $\Delta_{47}$ value (reported in the CDES, $25^{\circ} \mathrm{C}$ acid digestion scale using an acid fractionation factor of $+0.088 \%$ for $90^{\circ} \mathrm{C}$ acid digestion) and using the calibration of Petersen et al. [91], which is the most up-to-date available for carbonates of different mineralogies and sample types (synthetic, natural, or biogenic). This calibration includes the calibration dataset of Kele et al. [92], which is travertine/tufa-specific, and the synthetic carbonate calibration data of Kelson et al. [93], which was produced in IsoLab using the same methods as the sample data presented here.

The carbonate clumped isotope values measured at ATOMKI (Institute for Nuclear Research, Debrecen, Hungary) were performed using Thermo Scientific Kiel IV Automatic Carbonate Device coupled to a Thermo Scientific MAT253 Plus isotope ratio mass spectrometer. The measurement system was installed in 2018 in Isotope Climatology and Environmental Research Center (ICER). Each carbonate sample consisted of 10-12 replicate analyses of $100 \mu \mathrm{g}$ aliquots. ETH1, ETH2, and ETH3 were used as normalization 
standards, and IAEA-C2 was used as quality control sample with the values represented in Table S1 [90] of the supplementary material section. Data evaluation was carried out with Easotope application [94], using $\mathrm{CO}_{2}$ clumped ETH PBL replicate analysis method and Brand parameters (Table S2, in supplementary material section). $\Delta_{47}$ is reported in the CDES (carbon-dioxide equivalent scale) [90], using an acid fractionation fractor of $+0.066 \%$ to place data generated with $70^{\circ} \mathrm{C}$ acid digestion on the $25^{\circ} \mathrm{C}$ digestion scale, and temperatures were calculated using the calibration of Petersen et al. [91], to be comparable to the University of Washington data. For reference, we also report the temperature values calculated using the Kele et al. [92] calibration, recalculated with brand parameters: $\Delta_{47}=0.0449( \pm 0.001) \times\left(10^{6} / T^{2}\right)+$ $0.167( \pm 0.01)$, where $T$ is the temperature in Kelvin, because this calibration was produced using instrumentation similar to the ATOMKI instrument.

U-Th dating was performed to set up a reliable chronological frame for these banded carbonate veins, which are important records of fluid circulation. To this purpose, multicollector inductively coupled mass spectrometry (MC-ICPMS) [95] was applied to two samples (PAM1 and PAM13) at the High-Precision Mass Spectrometry and Environment Change Laboratory (HISPEC) of the National Taiwan University. About $0.05 \mathrm{~g}$ of each sample was dissolved in a concentrated $\mathrm{HNO}_{3}$ solution. The sample solution was spiked with a ${ }^{229} \mathrm{Th}^{233} \mathrm{U}^{236} \mathrm{U}$ tracer [96], and $0.5 \mathrm{ml}$ of $\mathrm{HClO}_{4}$ was added to decompose the organic matter. The final separation of uranium and thorium for MC-ICP-MS analysis was achieved by chemical methods [96], including Fe coprecipitation and anion-exchange chromatography. Single secondary electron multiplier protocols on a Thermo-Fisher NEPTUNE multicollection inductively coupled plasma mass spectrometer was used for determining the U-Th isotopic compositions and contents [95]. Offline data reduction methods followed Shen et al. [97], and half-lives of U-Th nuclides used for age determination are reported in Cheng et al. [98]. Analytical errors are $2 \sigma$ of the mean-age corrections, relative to $1950 \mathrm{AD}$, were calculated using an estimated atomic ${ }^{230} \mathrm{Th} /{ }^{232} \mathrm{Th}$ ratio of $4( \pm 2) \times 10^{-6}$.

\section{Results}

In the study area, several patches of fossil travertine deposits are exposed. In a few cases, deposition is still active. These deposits unconformably overlie Neogene-Quaternary and pre-Neogene units (i.e., Ligurian Units).

In the following sections, we illustrate the main stratigraphic and structural features of the travertine substratum. Then, the main stratigraphic and sedimentological features of the travertine deposits are reported, followed by a detailed description of the textural, mineralogical, geochemical and isotopic features of the banded Ca-carbonate veins, crossing the travertine deposits and filling fractures.

4.1. The Travertine Substratum. The travertine substratum (Figure 2) is formed by units stacked during the Northern Apennines evolution and orogenic belt building.
These are from the bottom (i) Palaeozoic-Mesozoic metamorphic rocks (Monticiano-Roccastrada Unit, CP, VER, and TCC in Figure 2); (ii) late Triassic-Oligocene sedimentary rocks (Tuscan Nappe, Ev, Di, Sc, and Mac in Figure 2); (iii) Cretaceous sandy-marl turbiditic succession (external Ligurian Unit); and (iv) Jurassic-Cretaceous ophiolite succession overlain by the marine shale and limestone cover (inner Ligurian Unit, Jc, and APA, respectively, in Figure 2).

The contractional tectonics that gave rise to the orogenic belt produced superimposed structures already described in several papers $[80,99,100]$. For the goals of this work, we focus on the Neogene-Quaternary extensional tectonics, which overprinted all the previously developed structures. Thus, low-angle normal faults (LANFs) caused the direct superimposition of the successions belonging to the uppermost unit (inner Ligurian Unit) either above the metamorphic rocks of the lowermost unit (Monticiano-Roccastrada Unit) or above the evaporite level forming the basal part of the Tuscan Nappe (Figure 2). This setting implies the lateral segmentation of several geological bodies as well as the partial or complete tectonic omission of the previously stacked units. Later, high-angle normal to oblique-slip faults, NWand NE-striking, dissected the LANFs and determined the eastern shoulder of the Volterra Basin, where the study area is located (Figure 2).

The Neogene sediments are mostly made up of sand, clay and sandy-clay with some conglomerate embedded at different levels. These sediments were deposited in the eastern margin of the Volterra Basin, recording its tectonic evolution, as documented in detail by Brogi and Liotta [61].

Travertine deposits are mainly located along the NE- and $\mathrm{NW}$-striking faults, overall at their intersection, which juxtaposes the Neogene sediments with the pre-Neogene units (e.g., nearby Iano village, Figure 2). In the southern part of the study area (e.g., near Il Palagio locality, Figure 2), the travertine deposits are in part still active and appear to be mainly related to NW-striking faults. NE- and NW-striking faults dissect Zanclean-Piacenzian sediments and, in a few cases, the travertine deposits, suggesting Quaternary activity, as discussed below.

The major faults are never exposed but their occurrence can be inferred by NE- and NW-striking scarps recognized across the whole area. Nevertheless, secondary faults are exposed in abandoned quarries or along road fresh cuts. These fault zones are characterized by apparent offsets of few meters and consist of damaged rock volumes exceeding $30 \mathrm{~m}$ in thickness with pervasive subvertical fractures and minor faults (Figures 3(a) and 3(b)). In some cases, hydrothermal alteration and/or localized mineralization (Figure 3) characterize fault planes and their damage zones. Fault slip planes are surrounded by fault cores, up to $10 \mathrm{~cm}$ thick, formed by brecciated rocks which, in some cases, show yellowish coatings as an effect of the circulation of previous geothermal fluids (Figure 3(a)).

Structural and kinematic data were collected in structural stations (Figure 2), in damaged rock volumes exposed in abandoned quarries where exposures and lithotypes are favorable to record and preserve striation on the slip surfaces. 

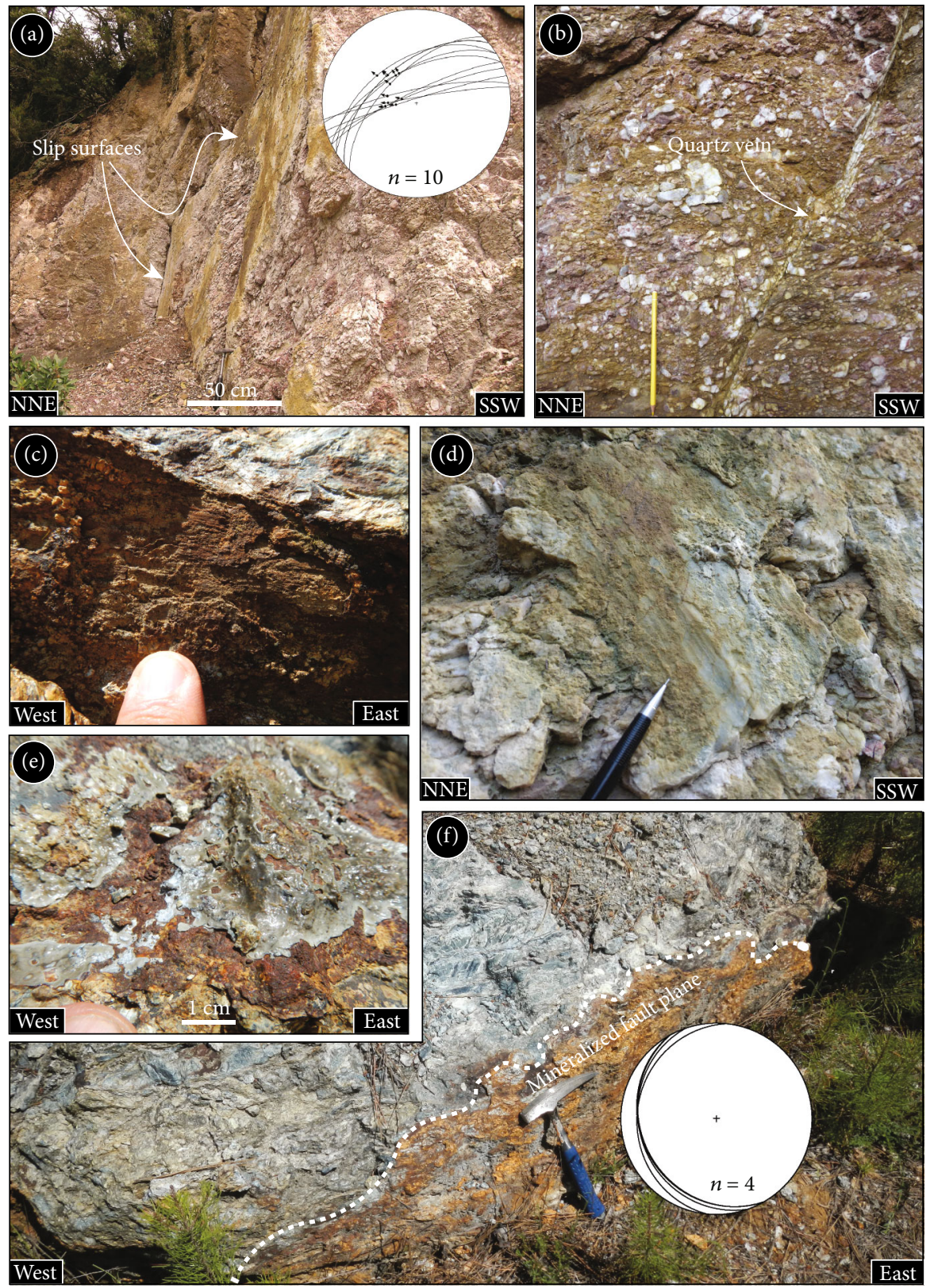

Figure 3: Examples of faults, minor structures, and evidences of hydrothermal fluid circulation. (a) A fault zone affecting the Verrucan group, showing yellowish patinas due to the hydrothermal fluid circulation. (b) Detail of a Qz-mineralized fracture affecting rocks of the Verrucano group. (c) slickenlines along the fault plane. (d) Detail of slicken lines along the fault plane in (a). (e) Detail of Fe-hydroxides and chalcedony coat. (f) A LANF affecting the ophiolite of the Ligurian unit characterized by Fe-hydroxides and chalcedony coat.

The results (Figure 4) indicate that the orientation of the analyzed mesofaults is in agreement with the regional-scale structures (Figure 2), thus displaying dominant NW- and NE-striking fault systems. Kinematic indicators mainly consist of mechanical striations (Figures 3(c) and 3(d)), chatter marks, lunate structures, tool marker and, in some cases, quartz and calcite slickensides, often accompanied by Fehydroxides crusts and patinas (Figures 3(e) and 3(f)). Kinematic indicators on the NE-striking faults show right- and left-lateral strike to oblique-slip movements, as well as normal ones (Figure 4). Their chronological relation was not defined, although it is likely that the normal movements are probably the last ones, based on chronologies that have been already described in the surrounding areas (cf. [68]). The NW-striking faults show dominant normal component, though left- and right-lateral oblique-slip movements have been locally observed (Figure 4).

These measurements from faults were used to derive the palaeostress field, assuming that the measured slickenlines are parallel to the main shear stress. Figure 4 shows the fault plane solutions obtained for each fault trend and their dominant kinematics. For the NE-striking faults, the maximum (compressional) and minimum axes are close to horizontal, while the intermediate axis is close to vertical, during the 
NE-striking left-lateral NE-striking right-lateral NE-striking normal NW-striking normal and oblique
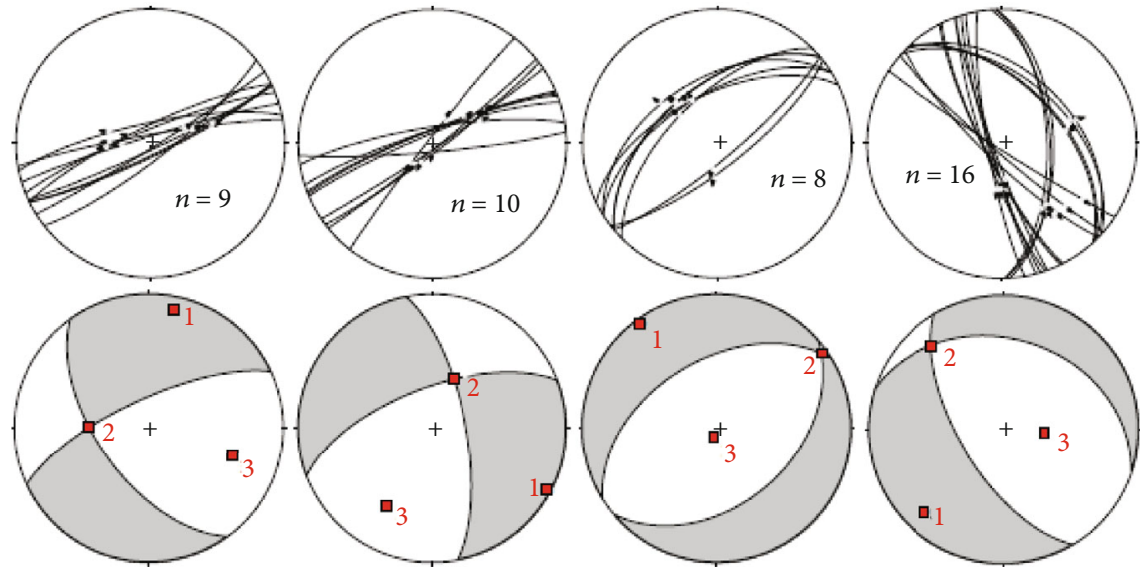

FIGURE 4: Stereographic diagrams (equiareal diagrams, lower hemisphere) illustrating faults, divided per fault trends, and kinematics and their relative focal mechanism.

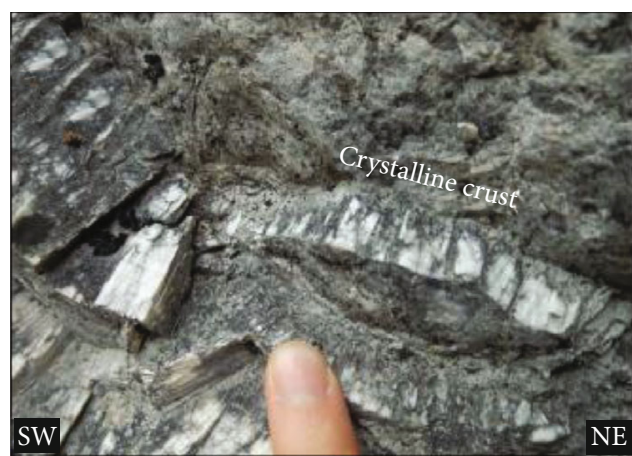

(a)

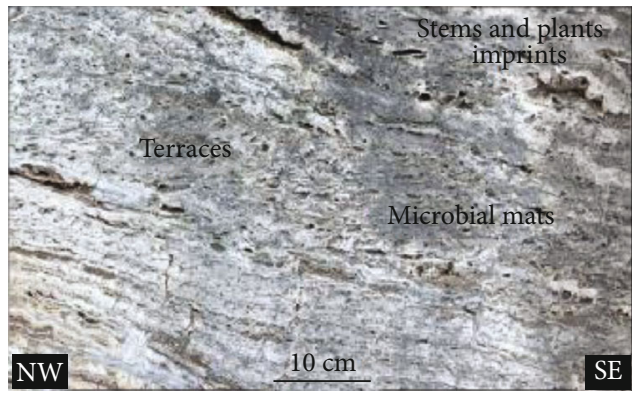

(c)

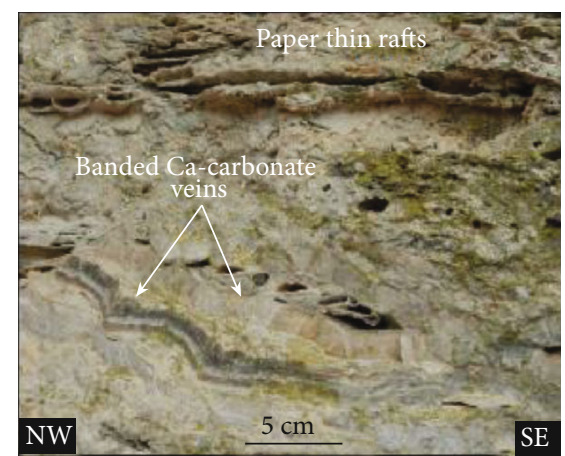

(b)

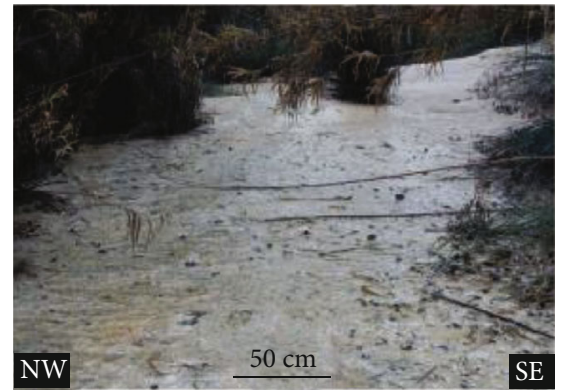

(d)

Figure 5: Main lithofacies of travertine deposits: (a) cm-thick crystalline crusts, (b) detail of paper thin raft overlying more compact travertine deposit cut by banded Ca-carbonate veins, (c) bedded travertine showing microterraces and alternation of microbial mats, with variable porosity, stem, and plants imprints, and (d) growing mound travertine.

right and left-lateral movement, which we hypothesize that occurred first. In contrast, the maximum axis is vertical, and the intermediate and minimum axes are subhorizontal during the later movement. Concerning the NW-striking faults, all axes are oblique.

4.2. The Travertine Depositional System. Travertine deposits consist of several bodies less than $1 \mathrm{~km}^{2}$ each, distributed in two different areas: (i) the Iano village area and its northern sector and (ii) Il Palagio area and its western sector (Figure 2).
The travertine patches of the Iano area are fossil deposits. These bodies are partly dismantled by human activity and covered by thick vegetation, and their original morphology cannot be reconstructed with complete confidence. Here, the maximum thickness of the travertine does not exceed $15 \mathrm{~m}$. According to the classification proposed by Capezzuoli et al. [101], travertine beds consist of laminated abiotic crystalline crusts (Figure 5(a)), microbial mats, and micritic beds. Deposits often encrust bushes and other plants (Figures 5(b) and 5(c)), suggesting a slope depositional system that passed to distal zones by subhorizontal morphology and low-energy 


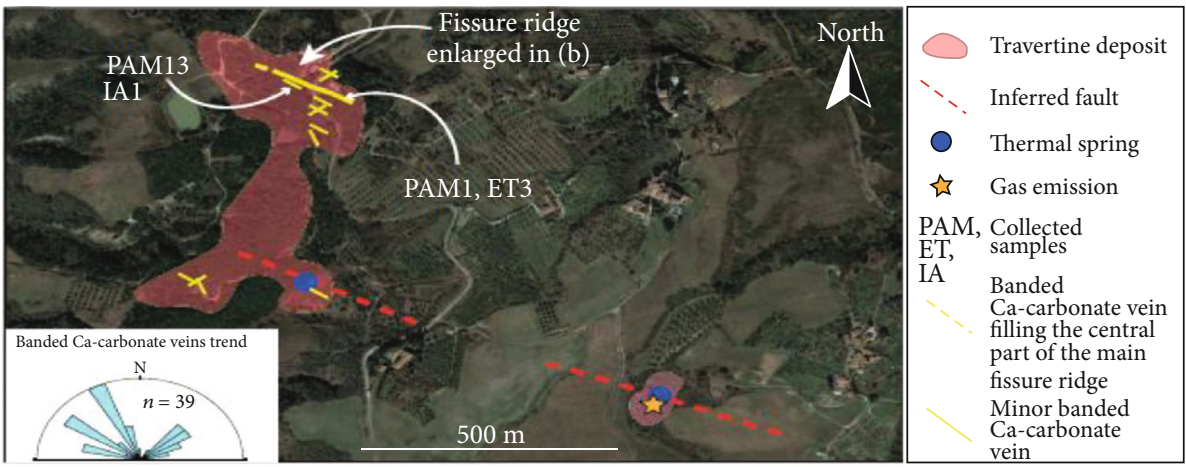

(a)

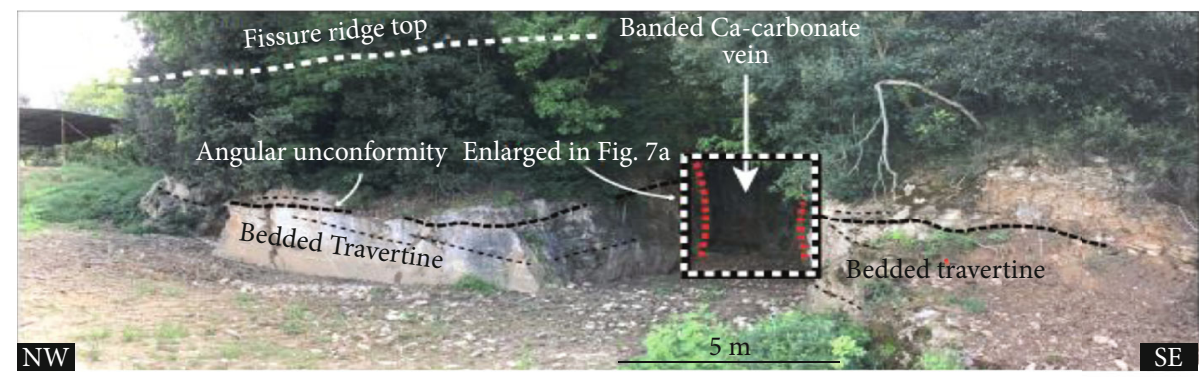

(b)

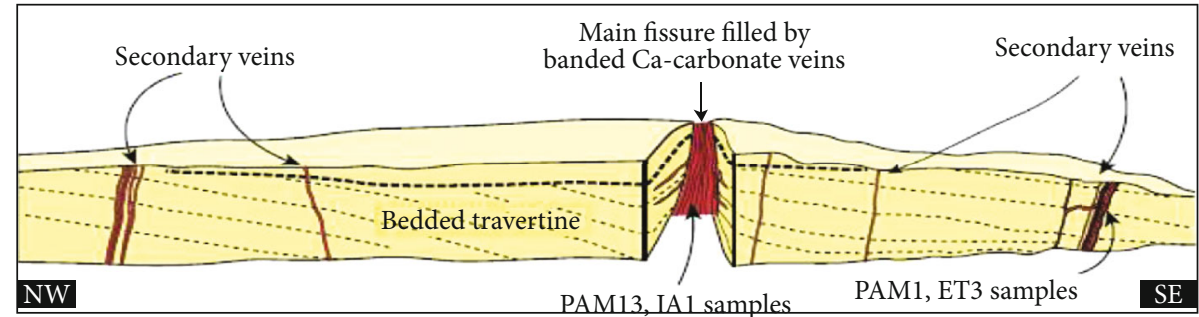

(c)

Figure 6: (a) Aerial photograph indicating the travertine deposit, the location of fissure ridge and gas emission, and collected samples; the orientation of the banded Ca-carbonate veins is also indicated in the rose diagram, (b) Fissure ridge made up of a central fracture completely filled by banded Ca-carbonate veins, showing the locations of samples PAM13 and IA1. (c) Schematic reconstruction of the travertine fissure ridge with the location of the collected samples.

environments. Facies distribution and bedding attitudes suggest cone-shaped mounds, indicating the location of the palaeothermal springs at their top. In this scenario, the travertine deposits were fed by thermal springs which deposited laminated abiotic crystalline crusts, interrupted by small ponds of microbial mats, and formed where fluids run along slopes, close to the palaeothermal springs. In the distal parts, fluids fed palustrine environments, where travertine deposited in vegetated areas suggest the cooling of the flowing waters.

The travertine patches in the Il Palagio area consist of two main bodies (Figures 2 and 6(a)). The smaller is only a few hundred square meters wide and consists of a partly dismantled fossil deposit, developed in the surroundings of a thermal water discharge area. The larger body is characterized by fossil deposits (Figure 6(b)) as well as an active thermal spring, causing present travertine deposition (Figure $5(\mathrm{~d})$ ) in its southern portion. From the active springs, a $22^{\circ} \mathrm{C}$ water is flowing, with a flow rate minor than 1 liter per second [102]. The water is characterized by $\mathrm{pH}=6.30$ and high
TDS values $(6665 \mathrm{mg} / \mathrm{L}), \mathrm{Ca}(\mathrm{Mg})-\mathrm{HCO}_{3}$, and high $\mathrm{Sr}$ and $\mathrm{SO}_{4}$ contents, accompanied by $\mathrm{CO}_{2}$ and $\mathrm{H}_{2} \mathrm{~S}$ leakage [11].

The fossil deposits were quarried and today, the abandoned saw cut walls are covered by thick vegetation. The fossil travertine body is defined by $\mathrm{NW}$-trending fissure ridge (Figures 6(a) and 6(b)) and aligned cone-shape mounds, revealing the main trend of the structures that controlled the hydrothermal fluid flow. Fissure ridges and travertine bodies are crossed by steeply dipping $\mathrm{cm}$ - to meters-thick Ca-carbonate veins, parallel to the main fault trends (Figure 6(a)), as described in detail in Section 4.3 in the next paragraph.

The main fissure ridge was deeply quarried, especially for the exploitation of banded Ca-carbonate veins crossing the central and lateral part of the body and corresponding to the feeding conduits of the palaeothermal springs. Moreover, small quarries are distributed along the fissure ridge, mainly following the meters thick central vein and the minor veins that cross the bedded travertine in the flanks of the ridge (Figure 6(b)). 


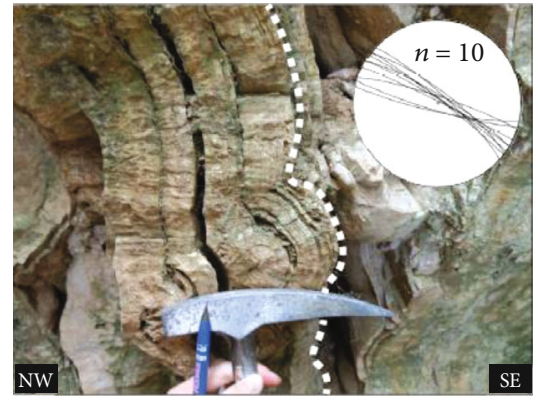

(a)

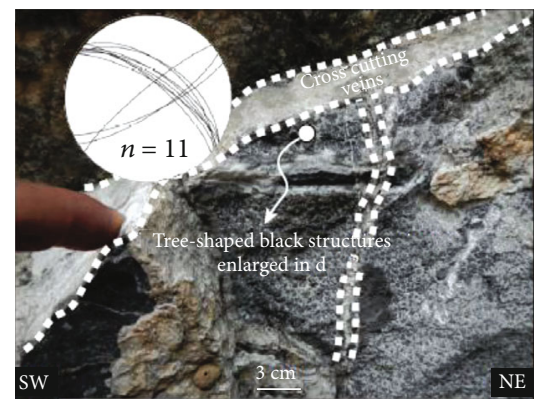

(c)

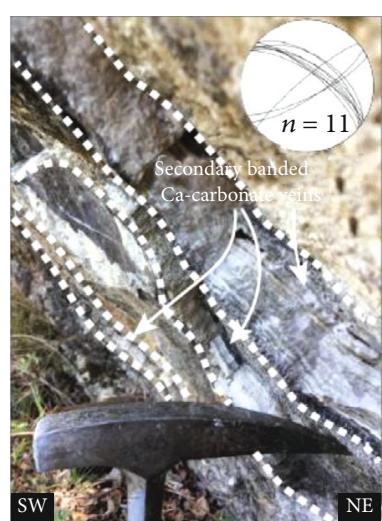

(b)

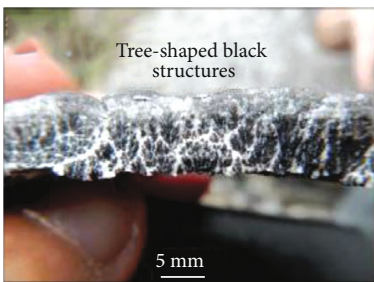

(d)

Figure 7: (a) Detail of banded Ca-carbonate vein showing a botryoid shape. (b) Detail of banded Ca-carbonate veins affecting the upper part of the fissure ridge. (c) Detail of NW-trending banded Ca-carbonate vein intersected by NE-trending banded vein. (d) Detail of black treeshaped structures affecting the external band of PAM1 sample.

4.3. Banded Ca-Carbonate Veins. Veins consist of onyx-like mm-sized crystalline bands in white, black, and brown. Bands are vertical or subvertical, with local dm-sized botryoids (Figure 7 (a)). The biggest vein (up to $2.10 \mathrm{~m}$ thick) is NW-trending and fills the central part of the ridge (Figures 6(b) and 6(c)), representing the main feeder conduit. Thinner veins (up to $10 \mathrm{~cm}$ thick) laterally cross the flank of the ridge (Figures 6(c) and 7(b)) mostly in the NW direction, accounting for secondary conduits. The veins are arranged in parallel bands, locally with internal unconformities crosscutting the previously formed bands; the unconformable contact relationships range from parallel to angular, thus recording an interruption in the crystallization. Some veins include black bands that look like tree-shaped structures (Figure $7(d)$ ) characterized by groups of branches in a white matrix. Their shape is very similar to the black "shrubs" identified by previous authors in travertine deposits in several localities such as Morocco (Africa), Bagni di Tivoli (Italy), Mammoth Hot Springs (Yellowstone National Park, USA) and Hierapolis (Turkey), [103-105]. Their thickness ranges from submillimeter to a few centimeters, forming thin laminae between vein bands (Figure 8(a)).

Each band is thought to correspond to a crack-and-seal event ([17], and references therein). Crack episodes mostly caused reopening of previously formed fractures. The new fracture developed parallel to slightly oblique with respect to the previously deposited bands, thus giving rise to a neoformational $\mathrm{mm}$ - to $\mathrm{cm}$-thick, geometrical irregular, syn- taxial veins (Figure $7(\mathrm{c})$ ). In some cases, the geothermal fluid permeated the mechanical discontinuities of the bedded travertine, thus producing $\mathrm{cm}$-thick syntaxial vein packages extending for meters, parallel to the bedded travertine strata (Figure 5(b)). These strata, mainly formed by abiotic crystalline crusts and made up of feather-like crystals and bedded porous laminae, are gently to steeply dipping (from $5^{\circ}$ to $50^{\circ}$ ).

We selected for further analysis key samples representing the main features of two different vein systems: (i) banded veins formed within the main fissure ridge feeder conduit (samples PAM13 and IA1 Figures 6(c), 7(a), and 9(a)) and (ii) banded veins crossing the flank (samples PAM1, ET3, Figures 6(c), 7(b), 8(a), and 10(d)). These latter recorded at least three superposed depositional events (V1, V2, V3), represented by crosscutting veins (Figure 8(a)). In particular, sample PAM1 recorded all three events (Figure 8(a)) and also includes black tree-shaped structures; in contrast, sample ET3 recorded V1 and V2 events (Figure 10(d)).

The sample location is indicated in Figures 6(a) and 6(c) and described in Table 1.

4.3.1. Mineralogy of Banded Ca-Carbonate Veins. Vein V1 of PAM1 (Figure 8(a)) and PAM13 (Figure 9(a)) samples was analyzed by XRD to identify the carbonate minerals. XRPD analysis reveals that the V1 diffractogram (Figure 8(b)) can be indexed to two carbonate phases: (i) aragonite, with the unit cell parameters of $a=4.9579(1), b=7.9778(2), c=$ 

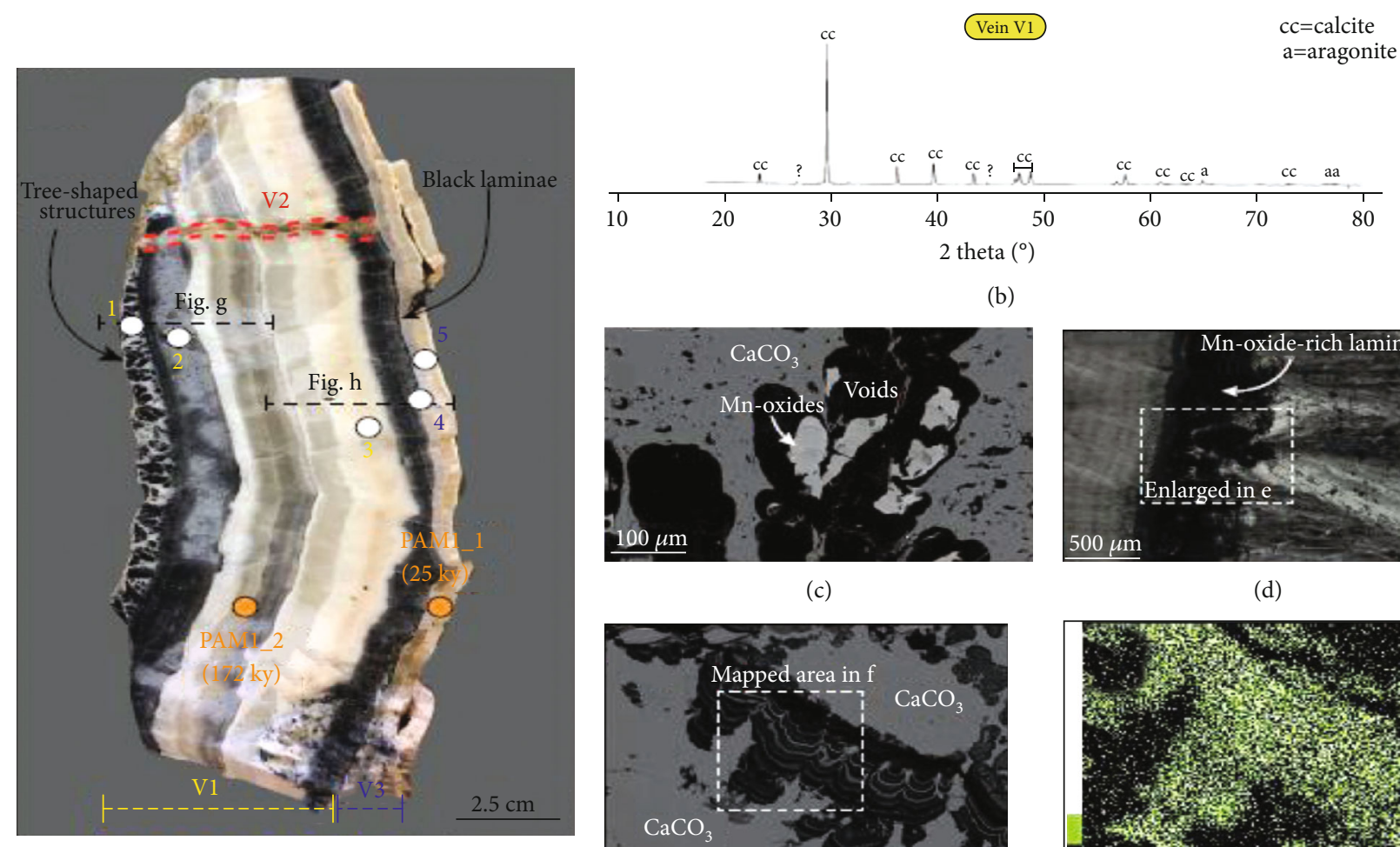

(b)

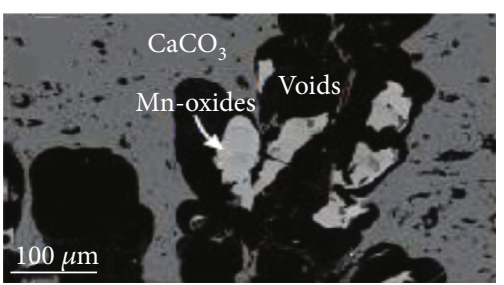

(c)

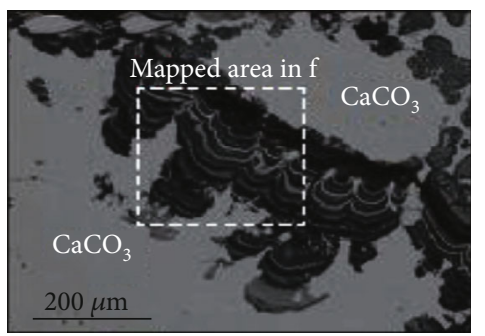

(e)

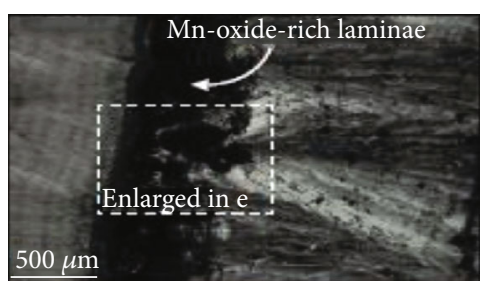

(d)

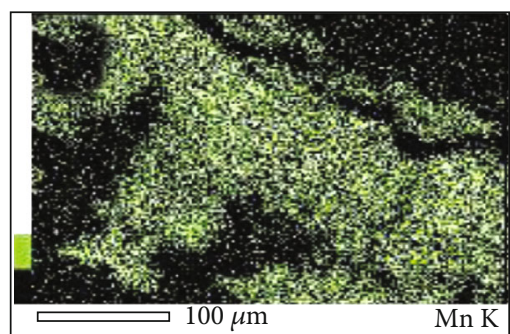

(f)

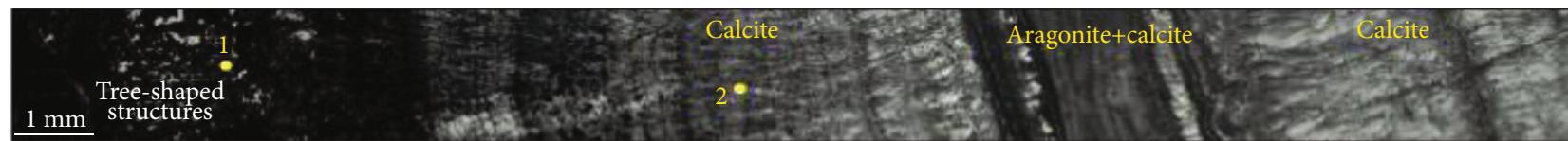

(g)

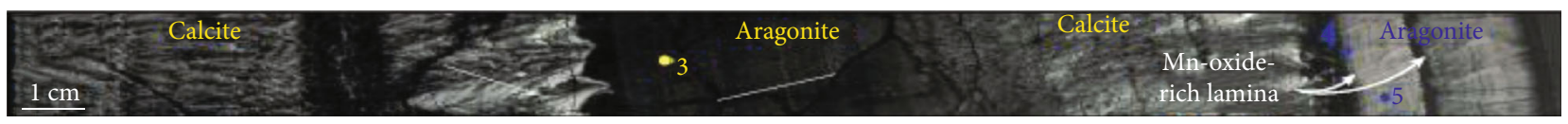

(h)

FIgure 8: Continued. 


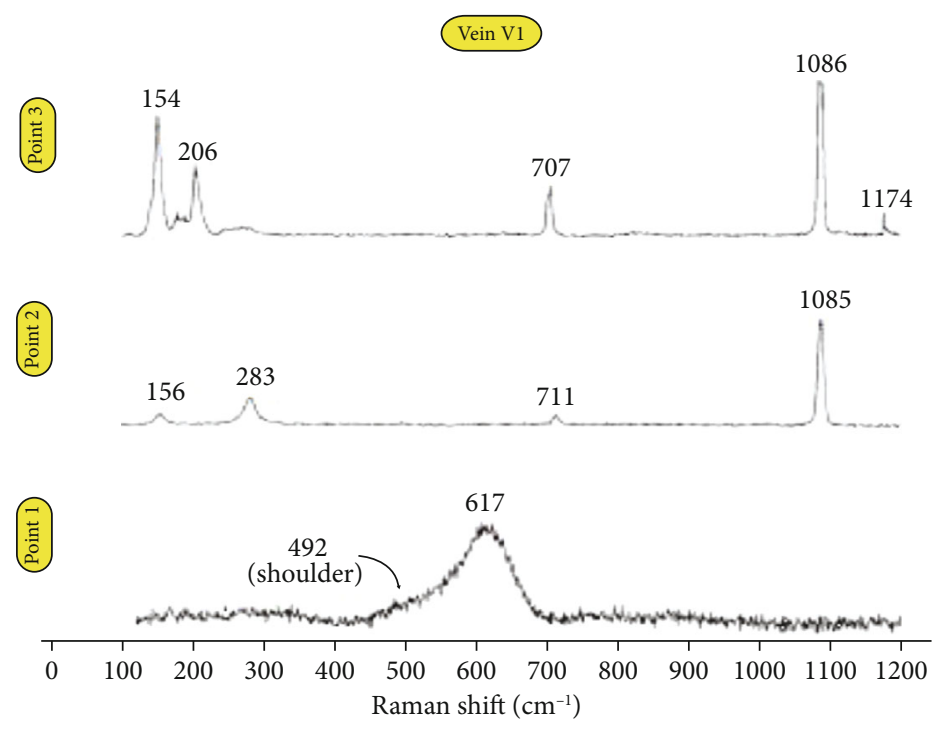

(i)

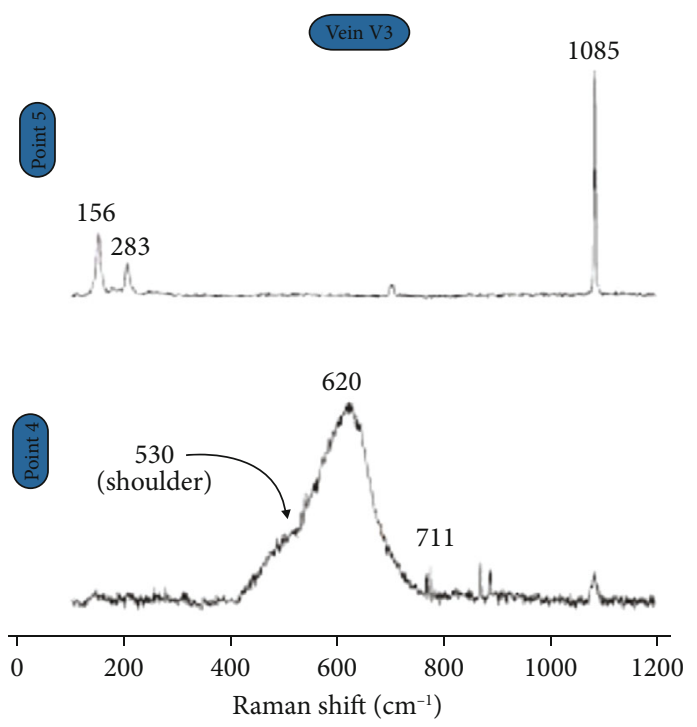

(j)

FIgURE 8: (a) PAM1 sample showing the bands of different colors and the three superimposed veins indicated with different colors and the acronyms V1, V2, and V. White circles indicate the analyzed point at micro-Raman. Orange circles named PAM1_1 and PAM1_2 indicate the bands used for U/Th datings. (b) XRPD pattern of vein V1. "?" refers to unknown peaks. (c) SEM image showing a detail of tree-shaped structures. The white part is characterized by $\mathrm{Mn}$-oxides located in $\mathrm{CaCO}_{3}$ matrix, and the voids suggest that the material has been removed. (d) Micrograph (crossed polars) showing detail of Mn-rich laminae in the PAM1 sample. (e) SEM image of the Mn-oxides lamina from PAM1 characterized by subrounded shape of different shades of gray. Brighter gray suggests a more important Mn-oxides concentration. (f) Chemical map of Mn-oxides lamina. (g, h) Micrograph (crossed polars) of the PAM1 sample showing bands made up of calcite and (Sr)-aragonite. The numbers refer to the points analyzed at micro-Raman. (i) Raman spectra of point 1, showing Mn-oxides band at $617 \mathrm{~cm}^{-1}$ with a shoulder at $492 \mathrm{~cm}^{-1}$, point 2 showing Calcite peaks, and point 3 showing aragonite peaks. (j) Raman spectra of point 4 showing Mn-oxides band at $620 \mathrm{~cm}^{-1}$ with a shoulder at $530 \mathrm{~cm}^{-1}$ and point 5 showing typical aragonite peaks.

5.7449(5) $\AA$, and space group Pmcn; and (ii) calcite, with the unit cell parameters $a=4.9713(1), c=17.017(3) \AA$, and space group $R-3 c$. The diffraction pattern also shows broad and low-intensity reflections located at $26.6^{\circ}$ and $44.6^{\circ}$ (indicated with the "?" symbol in Figure 8(b)), likely due to a poorly crystalline impurity phase that could not be indexed with calcite or aragonite phases. The cell parameters of calcite are slightly smaller than those present in the Joint Committee on Powder Diffraction Standards (JCPDS 47-1443), while the aragonite unit cell parameters deviate slightly from those for pure aragonite causing a small enlargement of cell volume (JCPDS 41-1475). Although calcite has a rhombohedral unit cell and aragonite is orthorhombic, both structures show similar Ca lattice but different $\mathrm{CO}_{3}{ }^{2-}$ ion arrangements. Carbonate structures can accommodate the trace element by exchange of $\mathrm{Ca}$ with $\mathrm{Mg}, \mathrm{Mn}, \mathrm{Fe}$, or $\mathrm{Sr}$, which is governed by the flexibility of the $\mathrm{Ca}$ site surrounding structure. The substitution causes dilation or contraction of the cell volume. Therefore, the small variation of cell volumes is associated with small amounts of larger and smaller sized ions substituting for $\mathrm{Ca}$ in the structure of aragonite and calcite, respectively [106-108]. To substantiate XRPD results, SEM/EDX analysis of calcite particles detected $\mathrm{Mg}, \mathrm{Ca}, \mathrm{C}$, and $\mathrm{O}$, whilst SEM/EDX of aragonite crystals detected $\mathrm{Sr}, \mathrm{Ca}$, and O. Confocal Raman analyses also support XRPD results. Indeed, the Raman spectra (Figure 8(i), points 2 and 3 ) of vein V1 (PAM1 sample) showed the typical vibration modes $v_{1}$ $\left(1085 \mathrm{~cm}^{-1}\right.$ calcite and $1086 \mathrm{~cm}^{-1}$ aragonite $)$ and $v_{4}\left(711 \mathrm{~cm}^{-1}\right.$ calcite and $705 \mathrm{~cm}^{-1}$ aragonite) for the $\mathrm{CO}_{3}$ group in a carbonate crystal lattice. Additional lattice mode peaks were located at $156 \mathrm{~cm}^{-1}, 282 \mathrm{~cm}^{-1}$ (calcite), and $207 \mathrm{~cm}^{-1}$ (aragonite). In addition, we used EDS to determine various elements at spots forming the black tree-shaped phase. The elemental mapping (Figure 8(f)) shows high intensities for manganese oxide, varying between $77.87 \%$ and $83.22 \%$. Micro-Raman spectra were also acquired in the sample PAM1, where black spots were clearly identified. All the Raman spectra show a strong wide band at about $620 \mathrm{~cm}^{-1}$ with shoulders at about 492 and $530 \mathrm{~cm}^{-1}$ (Figure $8(\mathrm{j}$ ), point 4 ). The spectra show the characteristic bands ascribed to natural manganese dioxide minerals [109]. Based on SEM/EDX and Raman analyses, the black material appears to consist of poorly defined manganese minerals (Figures 8(c) and 8(e)). Minor percentages of $\mathrm{MgO}$, $\mathrm{FeO}$, and $\mathrm{NiO}$ have been measured in the black deposits, with values around $2 \%, 1 \%$ (with some values higher than $5 \%$ ), and $5 \%$, respectively (see Table 2 for data).

For sample PAM13 (Figure 9(a)), the X-ray diffraction pattern (Figure 9(c)) reveals that the carbonate bands are made up predominantly of aragonite. Also, in this case, the cell parameters calculated from diffraction peaks $(a=4.9637(4)$, $b=7.9715(7), c=5.7473(5))$ indicate a slight dilation of the cell volume with respect to the ideal pure aragonite phase. Raman analyses (Figure 9(b)) confirm that the sample PAM13 is made up of aragonite, showing the typical aragonite peaks of the lattice modes located at $154 \mathrm{~cm}^{-1}, 207 \mathrm{~cm}^{-1}$, and $1086 \mathrm{~cm}^{-1}$. 


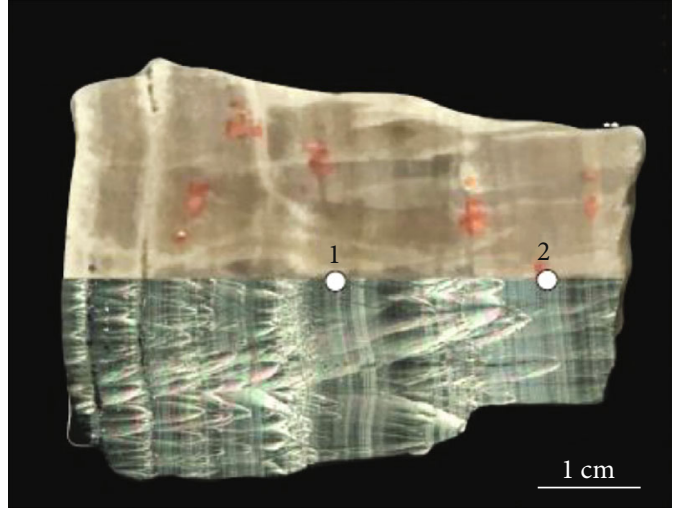

(a)

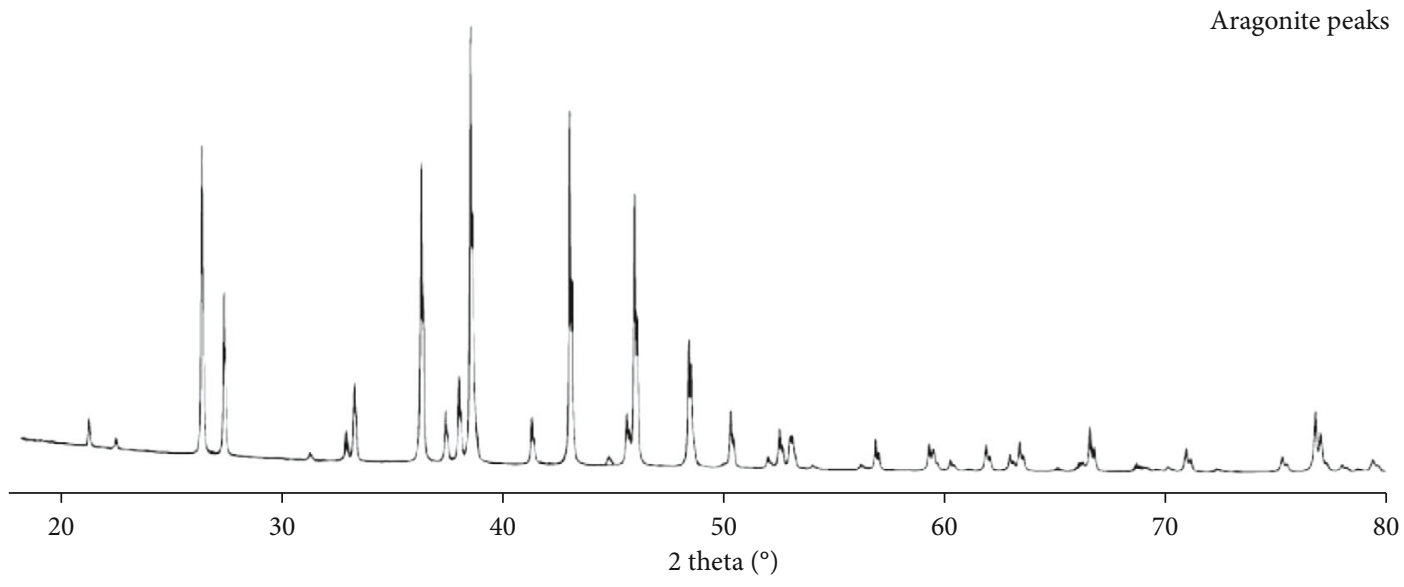

(c)

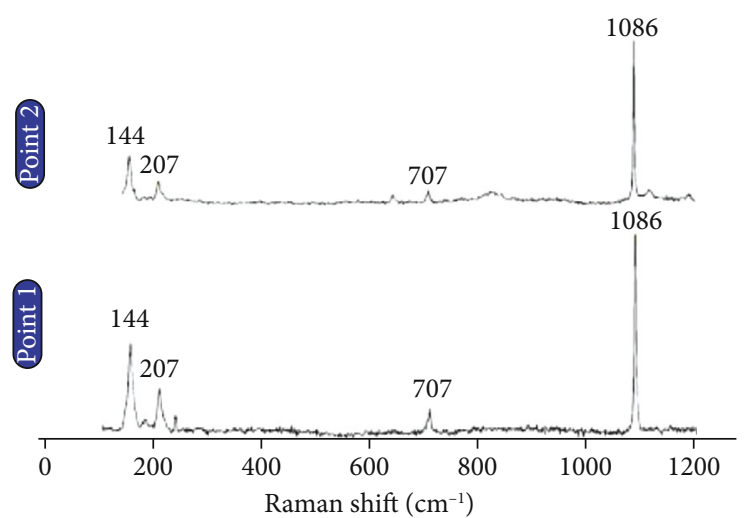

(b)

Figure 9: (a) Micrograph (crossed polars) of the PAM13 sample overlapping PAM13 hand specimen. White circles indicate the analyzed point at micro-Raman. (b) Raman spectra of points 1 and 2 showing typical aragonite peaks. (c) XRPD spectrum of the PAM13 sample.

\subsubsection{Textural Features and Age of the Banded $\mathrm{Ca}$-Carbonate} Veins. Vein V1 from sample PAM1 (Figure 8(a)) is mostly composed of mm-thick bands formed by elongate-blocky crystals of calcite or aragonite. The most external band (i.e., the primary formed band) is characterized by the presence of a $5 \mathrm{~mm}$-thick band, made up of black material simulating tree-shaped structures (Figures $7(\mathrm{~d})$ and $8(\mathrm{a})$ ), in a white $\mathrm{CaCO}_{3}$ matrix with scattered Mnoxides (cfr. 4.3.1 section). In some cases, the black material is organized in micrometer-thick laminae (Figures 8(a) and $8(\mathrm{~d})$ ) made up of multilayered, rounded or subrounded shapes (Figure 8(e)).

In the polished hand specimen of sample PAM1, calcite bands appear translucent and defined by different shades of gray. Calcite crystals consist of elongate-blocky crystals (Figure 10(a)), 150-300 $\mu \mathrm{m}$ wide, and from few millimeters to $5 \mathrm{~mm}$ long. Crystals enlarge in the growth direction, and their terminations are characterized by pointed curved faces (Figure 10(a)), suggesting that the crystals had the time to develop. Under crossed polars, these crystals show wavy extinction. Some calcite bands include black points, aligned perpendicularly to the growth direction (Figure 10(b)). These are made up of Mn-oxides, determining a dark color to the band, at the specimen scale (see Figure 8(a)).

Aragonite crystals confer a white, near opaque aspect to the bands in the polished hand specimen. The acicular aragonite crystals are made up of needle-like crystals extending along their $c$-axis direction (Figure $8(\mathrm{~g})$ ).

Calcite bands appear slightly darker gray on the backscattered images compared to the aragonite bands (Figure 10(c)). This is because calcite bands contain small percentages of $\mathrm{Mg}$ (3.25\%). In contrast, aragonite bands do not contain $\mathrm{Mg}$, but small percentages of $\mathrm{Sr}(3.08 \%)$, as also confirmed by the mineralogical analyses (cf. 4.3 .1 section).

Vein V2 shows a syntaxial fabric developed perpendicular to the V1 band. This crystal texture is well represented in sample ET3 (Figure 10(d)). Millimeter-sized voids are in the central part of the vein (Figure 10(e)); the lateral bands are made of small elongate-blocky calcite crystals (about $10 \mu \mathrm{m}$ in length) growing toward the central part of the vein (i.e., voids, in Figure 10(e)); dark hiatuses trace the edges of the elongate-blocky crystals (Figure 10(e)).

Vein V3 developed parallel to the V1 and interrupted the continuity of the V2 (Figure $8(\mathrm{a})$ ). The bands forming the 


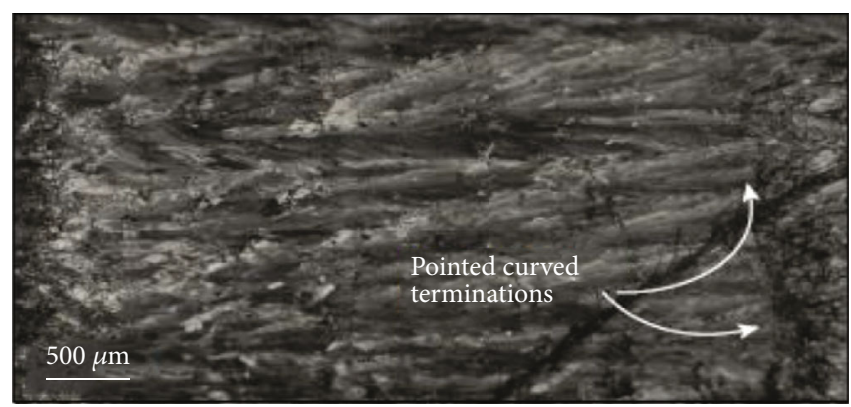

(a)

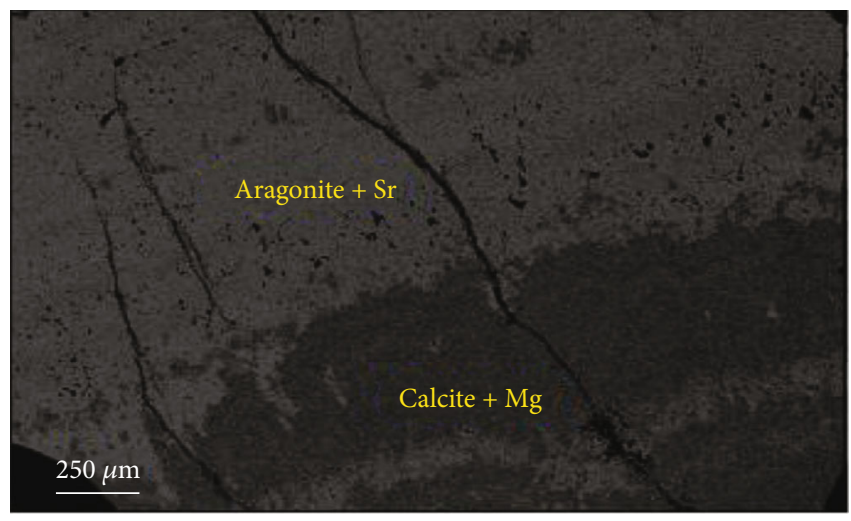

(c)

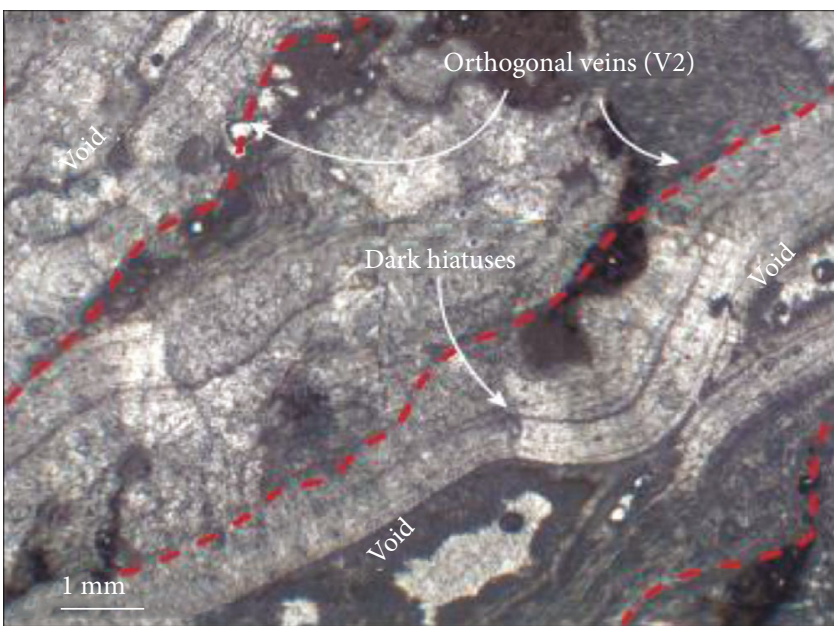

(e)

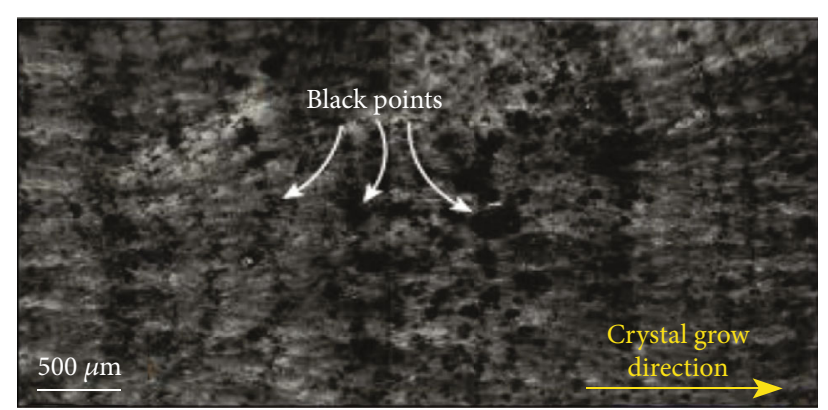

(b)

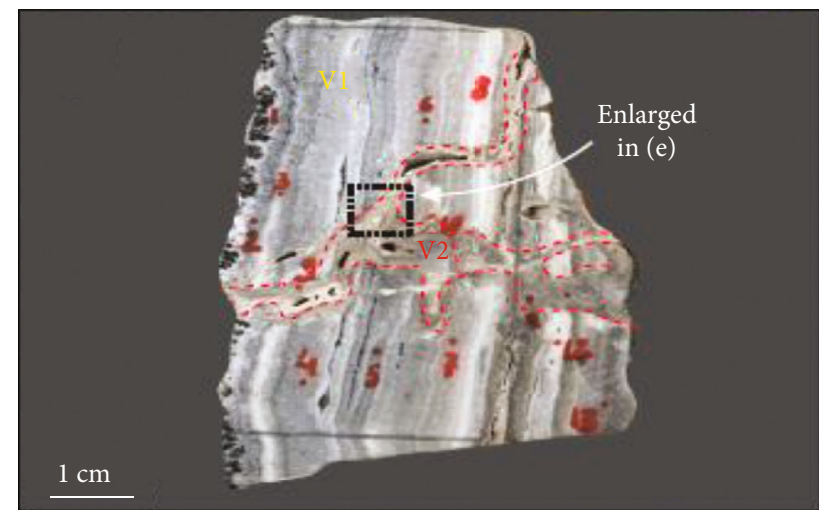

(d)

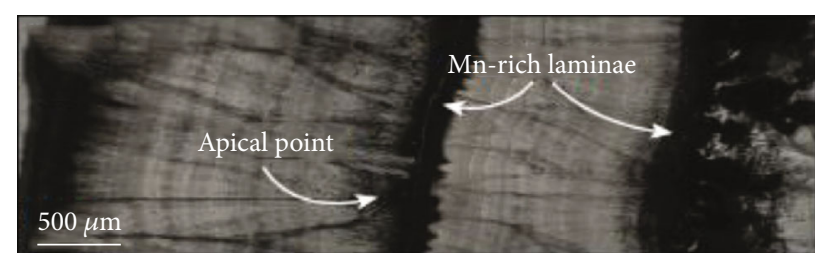

(f)

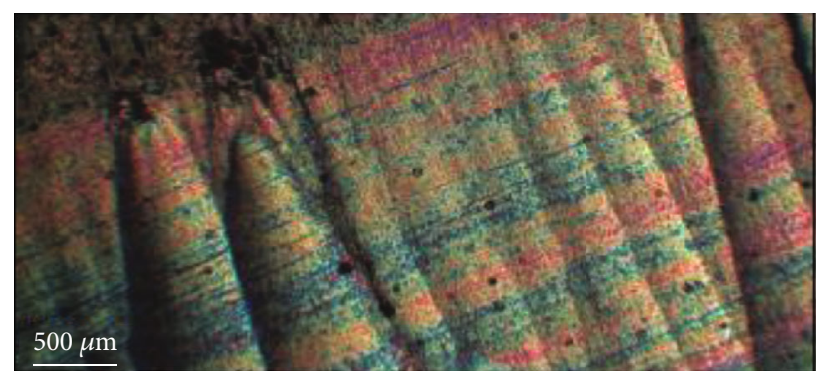

(g)

Figure 10: (a) Micrograph (crossed polars) of calcite crystals enlarging in the growth direction, showing their terminations characterized by pointed curved faces. (b) Micrograph (crossed polars) of calcite crystals perpendicularly crossed by aligned traces of Mn-oxides. (c) SEM image showing slightly darker calcite bands than aragonite ones, due to the presence of $\mathrm{Mg}$ in calcite crystals. (d) ET3 hand specimen showing vein V1 crossed by vein V2. (e) Micrograph (crossed polars) of part of the ET3 sample showing details of vein V2 characterized by millimeter-sized voids in the central part and small bands made up of elongate-blocky crystals growing toward the central part of the vein. (f) Micrograph (crossed polars) of vein V3 from the PAM1 sample showing acicular densely packed aragonite crystals, forming thin fans of ray crystals that develop from an apical point. (g) Micrograph (crossed polars) of the PAM13 sample showing needle-like aragonite crystals with very high interference colors.

vein V3 do not exceed $2 \mathrm{~mm}$ in thickness and are composed of acicular crystals of aragonite, showing a well-ordered texture (Figure 10(f)). The crystals are densely packed forming thin fans of ray crystals that develop from an apical point. Their ending faces form pointed terminations, highlighting that some crystals grew faster than others. Mn-oxide-rich lamina retrace the ending crystal faces (Figure 8(h)), separating vein V1 from vein V3.

Similar features are observed in sample PAM13, formed by parallel whitish bands (Figures 7 (a) and 9(a)). This vein is completely made of aragonite crystals. Aragonite bands are made up of elongated polycrystals ranging in length from 
TABLE 1: Coordinates of analyzed samples and type of analyses run for each sample.

\begin{tabular}{|c|c|c|c|c|c|c|c|c|}
\hline \multirow[b]{2}{*}{ Sample } & \multirow[b]{2}{*}{ Coordinates } & \multirow[b]{2}{*}{$\begin{array}{c}\text { Thin } \\
\text { section }\end{array}$} & \multirow[b]{2}{*}{$\begin{array}{l}\text { Stable } \\
\text { isotope }\end{array}$} & \multicolumn{2}{|c|}{ Analysis types } & \multirow[b]{2}{*}{$\begin{array}{c}\mathrm{RX} \\
\text { diffraction }\end{array}$} & \multirow[b]{2}{*}{$\mathrm{U} / \mathrm{Th}$} & \multirow[b]{2}{*}{$\begin{array}{l}\text { Clumped } \\
\text { isotopes }\end{array}$} \\
\hline & & & & Micro-Raman & SEM & & & \\
\hline \multicolumn{9}{|c|}{ PAM1 made up by $43^{\circ} 30^{\prime} 6.69^{\prime \prime} \mathrm{N}, 10^{\circ} 52^{\prime} 15.07 \mathrm{E}$} \\
\hline Vein V1 & & $\mathrm{X}$ & $\mathrm{X}$ & $\mathrm{X}$ & $\mathrm{X}$ & $\mathrm{X}$ & $\mathrm{X}$ & \\
\hline Vein V2 & & $\mathrm{X}$ & & & & & & \\
\hline Vein V3 & & $\mathrm{X}$ & $\mathrm{X}$ & $\mathrm{X}$ & $\mathrm{X}$ & & $\mathrm{X}$ & \\
\hline PAM13 & $43^{\circ} 30^{\prime} 8.81^{\prime \prime} \mathrm{N} 10,{ }^{\circ} 51^{\prime} 14.00^{\prime \prime} \mathrm{E}$ & $\mathrm{X}$ & $\mathrm{X}$ & $\mathrm{x}$ & $\mathrm{X}$ & $\mathrm{X}$ & $\mathrm{X}$ & \\
\hline ET3 & $43^{\circ} 30^{\prime} 06.8^{\prime \prime} \mathrm{N} 10,{ }^{\circ} 52^{\prime} 14.9^{\prime \prime} \mathrm{E}$ & $\mathrm{X}$ & $\mathrm{x}$ & & & & & \\
\hline IA 1 & $43^{\circ} 30^{\prime} 8.37^{\prime \prime} \mathrm{N}, 10^{\circ} 52^{\prime} 13.79^{\prime \prime} \mathrm{E}$ & & $\mathrm{X}$ & & & & & $\mathrm{X}$ \\
\hline
\end{tabular}

TABLE 2: Chemical composition of black tree-shaped structures in $\mathrm{wt} \%$.

\begin{tabular}{|c|c|c|c|c|c|c|c|}
\hline Analyzed points & $\mathrm{FeO}(\%)$ & $\mathrm{MnO}(\%)$ & $\mathrm{MgO}(\%)$ & $\mathrm{CaO}(\%)$ & $\mathrm{SrO}(\%)$ & $\mathrm{NiO}(\%)$ & Total \\
\hline 1 & 6.28 & 79.96 & 1.73 & 10.39 & 1.63 & 0 & 100 \\
\hline 2 & 5.6 & 80.24 & 2.28 & 9.25 & 2.63 & 0 & 100 \\
\hline 3 & 2.88 & 83.56 & 2.44 & 8.91 & 2.21 & 0 & 100 \\
\hline 4 & 3.41 & 83.68 & 1.54 & 8.81 & 2.56 & 0 & 100 \\
\hline 5 & 1.83 & 82.63 & 1.8 & 7.4 & 1.52 & 4.81 & 100 \\
\hline 6 & 0.89 & 82.55 & 2.36 & 7.32 & 1.2 & 5.69 & 100 \\
\hline 7 & 1.45 & 84.37 & 2.1 & 6.77 & 1.79 & 3.52 & 100 \\
\hline 8 & 1.46 & 84.37 & 2.1 & 6.75 & 1.83 & 3.49 & 100 \\
\hline 9 & 0.8 & 83.18 & 2.49 & 6.96 & 1.11 & 5.45 & 100 \\
\hline 10 & 0.96 & 81.97 & 2.49 & 7.96 & 0.28 & 6.34 & 100 \\
\hline 11 & 1.1 & 82.9 & 2.54 & 7.61 & 0 & 5.86 & 100 \\
\hline 12 & 1.31 & 83.55 & 2.7 & 7.5 & 0 & 4.93 & 100 \\
\hline
\end{tabular}

0.2 to $1.3 \mathrm{~cm}$ and resulting from the packing of needle thin crystals (Figure $10(\mathrm{~g})$ ). The latter shows wavy extinction caused by the systematic variation of the $c$-axis orientation with respect to the substratum of needle-like crystals [110] and very high interference colors (Figure $10(\mathrm{~g})$ ).

Two samples were selected for U-Th dating [95]: (i) V1 and V3 from sample PAM1, in order to get information on the time interval between the different veining events and (ii) sample PAM13. All samples are representative of a single band. The resulting data are summarized in Table 3. These highlight that V3 and V1 developed in a restricted time span encompassed between $26 \pm 1$ and $172 \pm 3$ thousand years ago (ka, before $1950 \mathrm{AD}$ ). In contrast, a radiometric age ranging between $21.1 \pm 0.1$ and $27.1 \pm 0.1 \mathrm{ka}$ was computed for the sample PAM13.

4.3.3. Stable and Clumped Isotope Analyses. The results of the $\delta^{13} \mathrm{C}$ and $\delta^{18} \mathrm{O}$ analyses of the veins (i.e., PAM1, ET3, and PAM13) indicate values ranging from $-1.2 \%$ to $4.2 \%$ (VPDB) and from $24.3 \%$ to $26.8 \%$ (V-SMOW), respectively. These ranges of values can be ascribed to the group of thermogenic travertine (see [5]).

The dataset is reported in Table 4 and displayed in the diagram of Figure 11(a).
Vein 1 from PAM1 $(n=12)$ and $\operatorname{ET3}(n=10)$ samples (Figures $8(\mathrm{a})$ and $10(\mathrm{~d})$ ) is characterized by $\delta^{13} \mathrm{C}$ and $\delta^{18} \mathrm{O}$ values ranging from $-1.2 \%$ to $1.5 \%$ (V-PDB) and $24.3 \%$ to $26.3 \%$ (V-SMOW), respectively. $\delta^{13} \mathrm{C}$ and $\delta^{18} \mathrm{O}$ values of vein $\mathrm{V} 2(n=3)$ range from $-0.1 \%$ to $1.4 \%$ (V-PDB) and $25.6 \%$ to $26.0 \%$ o (V-SMOW), respectively. V1 data are consistent with those from vein $\mathrm{V} 2$, suggesting constant fluid properties during fracturing. However, although the $\delta^{18} \mathrm{O}$ data of vein $\mathrm{V} 3(n=3)$ are similar to $\mathrm{V} 1$ and $\mathrm{V} 2, \delta^{13} \mathrm{C}$ data show different values, ranging from $2.5 \%$ o to $4.2 \%$ (V-PDB).

Similarly, the vein from the main feeder conduit of the fissure ridge (PAM13, $n=31$ ) is characterized by $\delta^{13} \mathrm{C}$ and $\delta^{18} \mathrm{O}$ values ranging from $2.9 \%$ to $4.2 \%$ (V-PDB) and from $25.7 \%$ o to $26.8 \%$ o (V-SMOW), respectively.

On the basis of $\delta^{13} \mathrm{C}$ values, data can be separated in two distinct groups. The veins crossing the flank of the fissure ridge (Figure $6(\mathrm{c})$ ) are characterized by lower $\delta^{13} \mathrm{C}$ values with respect to those defining the vein from the feeder conduit. $\delta^{18} \mathrm{O}$ values are very similar for the two vein types, although PAM13 and V3 samples show slightly higher values than those from V1 and V2 veins. Stable isotope values of vein V3 fall between the two groups (Figure 11(a)).

Clumped isotope composition $\left(\Delta_{47}\right)$ was measured on a band of aragonitic sample (IA1) from the central part of the 


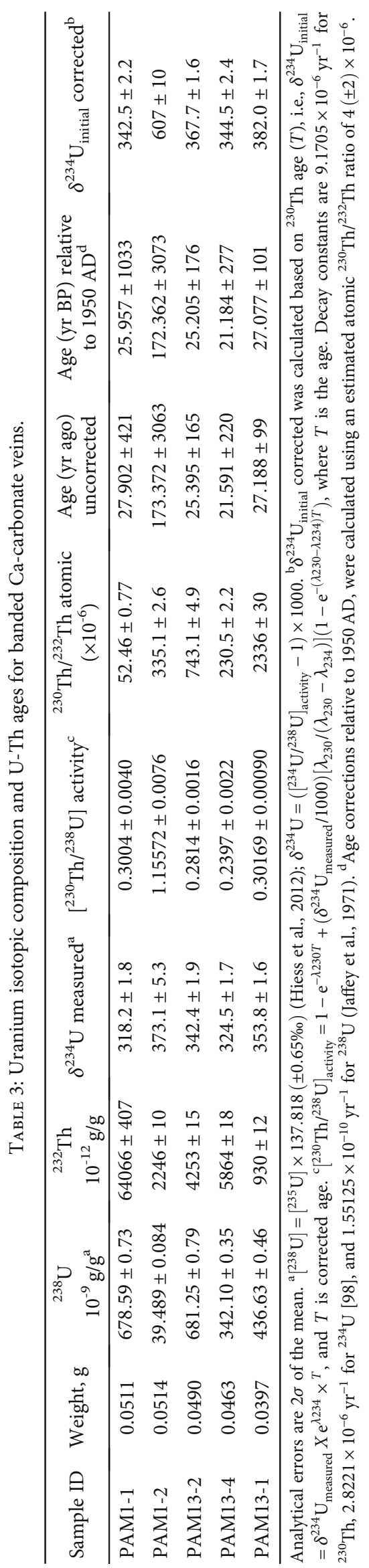


TABLE 4: Results of the stable isotopes analyses.

\begin{tabular}{|c|c|c|c|c|}
\hline Sample & Mineralogy & $\delta^{13} \mathrm{C}(\%, \mathrm{~V}-\mathrm{PDB})$ & $\delta^{18} \mathrm{O}(\%, \mathrm{~V}-\mathrm{PDB})$ & $\delta^{18} \mathrm{O}(\%, \mathrm{~V}-\mathrm{SMOW})$ \\
\hline PAM1_16 & Aragonite & 4.2 & -4.4 & 26.3 \\
\hline PAM1_15 & Aragonite & 2.5 & -5.9 & 24.8 \\
\hline PAM1_14 & Aragonite & 3.6 & -5.1 & 25.7 \\
\hline PAM1_13 & Mn-oxide lamina & -1.2 & -5.6 & 25.2 \\
\hline PAM1_12 & Calcite & 0.0 & -5.8 & 24.9 \\
\hline PAM1_11 & Calcite & 0.0 & -5.8 & 24.9 \\
\hline PAM1_10 & Aragonite & 1.5 & -6.0 & 24.7 \\
\hline PAM1_9 & Aragonite & 1.2 & -6.1 & 24.6 \\
\hline PAM1_8 & Calcite & -0.1 & -6.4 & 24.3 \\
\hline PAM1_7 & Blocky/chaotic & 0.9 & -6.0 & 24.7 \\
\hline PAM1_6 & Calcite & 0.1 & -6.0 & 24.7 \\
\hline PAM1_5 & Calcite & -0.2 & -5.7 & 25.0 \\
\hline PAM1_4 & Aragonite + calcite & 1.5 & -5.8 & 24.9 \\
\hline PAM1_3 & Calcite & 0.1 & -5.6 & 25.1 \\
\hline PAM1_2 & Calcite & -0.3 & -5.7 & 25.0 \\
\hline PAM1_1 & Tree-shaped structures & -0.4 & -5.4 & 25.3 \\
\hline PAM13_1_8 & Aragonite & 3.2 & -5.0 & 25.7 \\
\hline PAM13_1_7 & Aragonite & 3.6 & -5.0 & 25.8 \\
\hline PAM13_1_6 & Aragonite & 3.4 & -4.7 & 26.1 \\
\hline PAM13_1_5 & Aragonite & 3.8 & -4.9 & 25.9 \\
\hline PAM13_1_4 & Aragonite & 3.3 & -4.8 & 25.9 \\
\hline PAM13_1_3 & Aragonite & 3.2 & -4.6 & 26.2 \\
\hline PAM13_1_2 & Aragonite & 3.8 & -4.2 & 26.5 \\
\hline PAM13_1_1 & Aragonite & 3.6 & -4.6 & 26.2 \\
\hline PAM13_2_1 & Aragonite & 3.2 & -4.7 & 26.0 \\
\hline PAM13_2_2 & Aragonite & 3.1 & -4.5 & 26.2 \\
\hline PAM13_2_3 & Aragonite & 3.5 & -4.4 & 26.4 \\
\hline PAM13_2_4 & Aragonite & 4.0 & -4.0 & 26.8 \\
\hline PAM13_2_5 & Aragonite & 3.9 & -4.0 & 26.8 \\
\hline PAM13_2_6 & Aragonite & 4.2 & -4.2 & 26.6 \\
\hline PAM13_2_7 & Aragonite & 3.8 & -4.3 & 26.4 \\
\hline PAM13_4_1 & Aragonite & 3.6 & -4.7 & 26.1 \\
\hline PAM13_4_2 & Aragonite & 3.0 & -5.1 & 25.7 \\
\hline PAM13_4_3 & Aragonite & 3.2 & -5.0 & 25.7 \\
\hline PAM13_4_4 & Aragonite & 3.8 & -4.5 & 26.3 \\
\hline PAM13_4_5 & Aragonite & 3.4 & -4.8 & 26.0 \\
\hline PAM13_4_6 & Aragonite & 3.5 & -4.3 & 26.5 \\
\hline PAM13_4_7 & Aragonite & 3.6 & -4.7 & 26.1 \\
\hline PAM13_4_8 & Aragonite & 3.6 & -4.8 & 25.9 \\
\hline PAM13_4_9 & Aragonite & 3.9 & -4.4 & 26.3 \\
\hline PAM13_4_10 & Aragonite & 4.1 & -4.3 & 26.5 \\
\hline PAM13_4_11 & Aragonite & 4.1 & -4.6 & 26.1 \\
\hline PAM13_4_12 & Aragonite & 3.8 & -4.7 & 26.1 \\
\hline PAM13_4_13 & Aragonite & 4.0 & -4.3 & 26.5 \\
\hline PAM13_4_14 & Aragonite & 4.0 & -4.6 & 26.2 \\
\hline ET-3_1 & Tree-shaped structures & -0.3 & -5.6 & 25.1 \\
\hline ET-3_2 & Chaotic & 0.1 & -5.7 & 25.0 \\
\hline ET-3_3 & Aragonite & -0.2 & -5.6 & 25.1 \\
\hline
\end{tabular}


TABLE 4: Continued.

\begin{tabular}{lcccc}
\hline Sample & Mineralogy & $\delta^{13} \mathrm{C}(\% 0, \mathrm{~V}-\mathrm{PDB})$ & $\delta^{18} \mathrm{O}(\% 0, \mathrm{~V}-\mathrm{PDB})$ & $\delta^{18} \mathrm{O}(\% 0, \mathrm{~V}-\mathrm{SMOW})$ \\
\hline ET-3_4 & Chaotic & -0.2 & -5.8 & 24.9 \\
ET-3_5 & Chatic & -0.2 & -6.2 & 24.5 \\
ET-3_6 & Calcite & 0.0 & -6.4 & 24.4 \\
ET-3_7 & Calcite & 0.0 & -5.8 & 24.9 \\
ET-3_8 & Aragonite & 0.9 & -5.4 & 25.3 \\
ET-3_9 & Calcite & 1.2 & -5.1 & 25.6 \\
ET-3_10 & Calcite & 1.4 & -5.0 & 25.8 \\
ET-3_11 & Calcite & -0.1 & -4.8 & 26.0 \\
ET-3_12 & Aragonite & -0.5 & -4.5 & 26.3 \\
ET-3_13 & Calcite & -0.6 & -5.7 & 25.0 \\
IA1_W & Aragonite & 2.5 & -5.9 & 24.9 \\
IA2_D & Aragonite & 3.2 & -5.3 & 25.5 \\
\hline
\end{tabular}

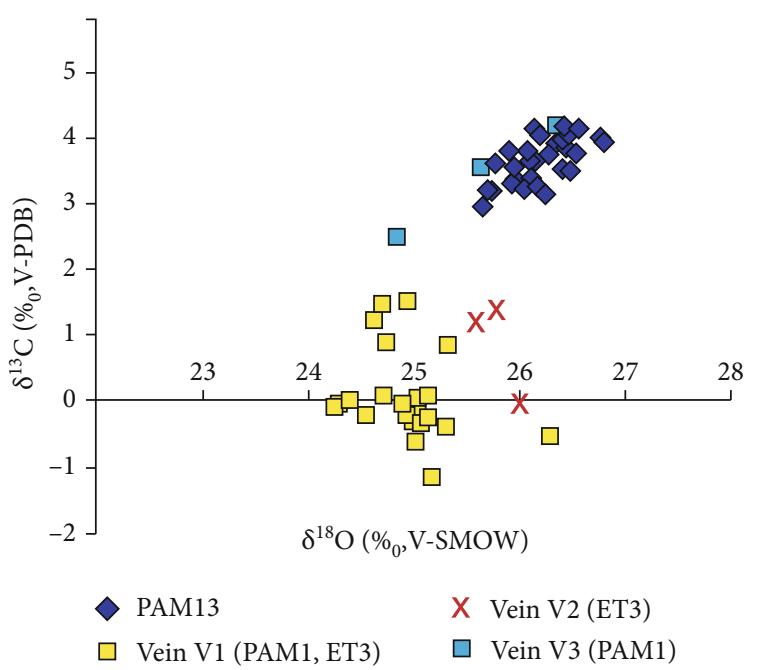

(a)

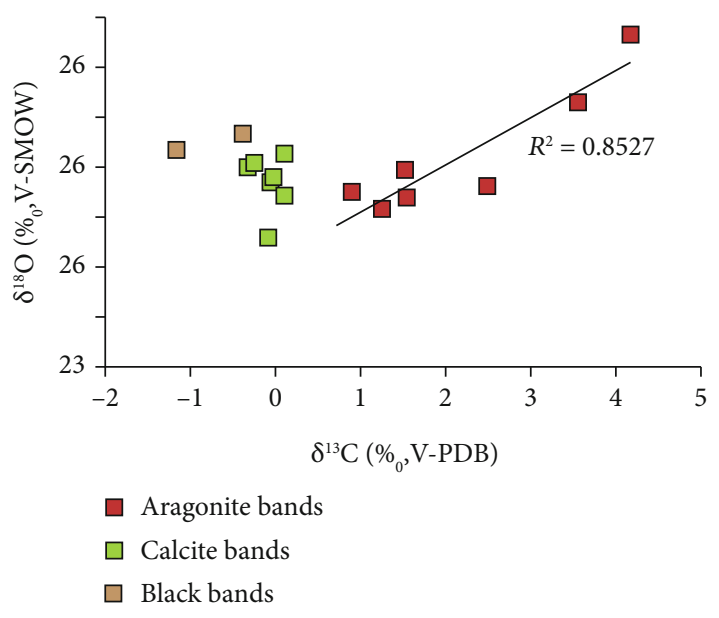

(b)

FIgURe 11: (a) Graph showing the distribution of stable isotope data for the analyzed samples. Blue rhombus refers to the PAM13 data; yellow square refers to the vein V1 data from PAM1 and ET3; the symbol "x" refers to the vein V2 from ET3; pale blue square refers to the vein V3 data from the PAM1 sample. (b) PAM1 isotope data distinguished on the basis of their mineralogy. See the good correlation $\left(R^{2}=0.8527\right)$ between stable isotopes of aragonite crystals.

TABLE 5: Results of the clumped isotopes analyses.

\begin{tabular}{lccccccccc}
\hline Sample & Replicates & $\begin{array}{c}\delta^{13} \mathrm{C} \\
(\mathrm{VPDB}, \%)\end{array}$ & $\begin{array}{c}\delta^{13} \mathrm{C} \\
\text { stdev }\end{array}$ & $\begin{array}{c}\delta^{18} \mathrm{O} \\
(\mathrm{VPDB}, \% 0)\end{array}$ & $\begin{array}{c}\delta^{18} \mathrm{O} \\
\text { stdev }\end{array}$ & $\begin{array}{c}\Delta_{47} \text { (average, } \\
\mathrm{CDES25} \%)\end{array}$ & $\begin{array}{c}\Delta_{47} \text { std error } \\
(\%)\end{array}$ & $\begin{array}{c}\Delta_{47} \text { std error } \\
\text { based on long-term } \\
\text { stdev of carbonate } \\
\text { standards (\%) }\end{array}$ & $\begin{array}{c}T\left({ }^{\circ} \mathrm{C}\right) \text { cal. } \\
\text { With Petersen } \\
\text { et al. [91] }\end{array}$ \\
\hline IA 1 & 2 & 2.819 & 0.050 & -5.231 & 0.017 & 0.589 & 0.003 & 0.012 & 67 \\
IA1_d & 17 & 3.230 & 0.050 & -5.260 & 0.090 & 0.558 & 0.008 & 0.006 & 84 \\
IA1_w & 14 & 2.660 & 0.050 & -5.750 & 0.090 & 0.518 & 0.007 & 0.006 & 5 \\
\hline
\end{tabular}

ridge (in the proximity of PAM13 location), in order to reconstruct the palaeotemperature of the fluids that deposited the $\mathrm{Ca}$-carbonate veins. The calculation gave a temperature of $67^{\circ} \mathrm{C} \pm 6^{\circ} \mathrm{C}$. Clumped isotope composition was determined at ATOMKI in order to calculate palaeotemperature on two other bands of the IA1 sample, which gave values of $84^{\circ} \mathrm{C} \pm 5^{\circ} \mathrm{C}$ and $111^{\circ} \mathrm{C} \pm 5^{\circ} \mathrm{C}$, respectively. The data are reported in Table 5 . In addition, we also report the temperature values calculated using Kele et al.'s [92] calibration for these last two values, for the reasons explained i Section 3.2. The calculation gave temperatures of $68^{\circ} \pm 4^{\circ} \mathrm{C}$ and $85^{\circ} \pm$ $3^{\circ} \mathrm{C}$, which are more suitable for the geothermal system of 
the study area. These values partially confirm the temperature value computed at the University of Washington. For this reason, we consider a fluid temperature range between $67^{\circ} \mathrm{C} \pm 6^{\circ} \mathrm{C}$ and $85^{\circ} \mathrm{C} \pm 3^{\circ} \mathrm{C}$.

\section{Discussion}

The discussion focuses on three main points: (i) fluid origin, (ii) tectonic control on the fluid flow, and (iii) role of geochemistry in reconstructing the geothermal fluid property variations and the possible triggering factors.

5.1. Fluid Origin. Geothermal fluids that formed the travertine deposits interacted with carbonate and sulfate rocks, as suggested by their high potential to deposit $\mathrm{Ca}$-carbonate and by their Sr content [11]. This implies that the geothermal fluids flowed within the late Triassic evaporite and Jurassic carbonate located at the base of the Tuscan Nappe [36, 111]. It is known that in the neighboring Larderello area, the geothermal fluids are mostly of meteoric origin $(>95 \%)$ with a minor inflow of thermometamorphic and magmatic fluids [112-114]. It is therefore reasonable to assume that the parent fluids of the travertine would be related to meteoric waters, too.

Regarding the presence of $\mathrm{CO}_{2}$, this can be the result of different processes [115]: (i) mantle degassing [116, 117], (ii) limestone dissolution [118], or (iii) hydrothermal metamorphism of limestone [119]. On the basis of $\delta^{13} \mathrm{C}_{\mathrm{CO} 2}$, the potential source for $\mathrm{CO}_{2}$ can be discerned: (a) $-7 \% 0<\delta^{13}$ $\mathrm{C}_{\mathrm{CO} 2}<-4 \%$ (V-PDB) suggests mantle degassing [120], (b) $\delta^{13} \mathrm{C}_{\mathrm{CO} 2}=-7 \%$ (V-PDB) indicates dissolved $\mathrm{CO}_{2}$ in rainwater in equilibrium with atmospheric $\mathrm{CO}_{2}[121]$, (c) $\delta^{13} \mathrm{C}_{\mathrm{CO} 2}$ $<-20 \%$ (V-PDB) drives at biogenic $\mathrm{CO}_{2}$ [122], and (d) $-1 \% 0<\delta^{13} \mathrm{C}_{\mathrm{CO} 2}<+2 \%$ (V-PDB) suggests $\mathrm{CO}_{2}$ from hydrothermal processes [123].

In our case, we computed $\delta^{13} \mathrm{C}_{\mathrm{CO} 2}$ values from the carbonate $\delta^{13} \mathrm{C}$ values of the study veins, using the empirical equation $\left(\delta^{13} \mathrm{C}_{\mathrm{CO} 2}=1.2 \delta^{13} \mathrm{C}_{\text {trav. }}-10.5\right)$ of Panichi and Tongiorgi [118], resulting from the comparison between the Italian thermal springs and associated travertine deposits. The $\delta^{13} \mathrm{C}_{\mathrm{CO} 2}$ calculations for $\mathrm{V} 1$ and $\mathrm{V} 2$ veins give values ranging from $-12 \%$ to $-9 \%$ (V-PDB). In contrast, the computed $\delta^{13} \mathrm{C}_{\mathrm{CO} 2}$ values for $\mathrm{V} 3$ vein and for banded veins from the central fissure of the ridge are slightly higher, ranging from $-7 \%$ to $-5 \%$ (V-PDB). Interestingly, the computed $\delta^{13} \mathrm{C}_{\mathrm{CO} 2}$ values are significantly lower than most of the $\mathrm{CO}_{2}$ gas emissions in central Italy, which vary from $-2 \%$ to $+2 \%$ (V-PDB, [124]).

As previously said, banded Ca-carbonate veins are the results of crack-and-seal events, likely triggered by the tectonic activity. This process could account for the variation of $\mathrm{pCO}_{2}$ (probably due to tectonic activity) during the multistep precipitation of banded Ca-carbonate veins, from fluids that migrated from depth to the surface. According to Minissale et al. [115], this process could produce a large isotopic fractionation, causing the deposition of banded Ca-carbonate veins that are enriched in ${ }^{13} \mathrm{C}$ at depth. As a consequence, the rising fluid, depleted in ${ }^{13} \mathrm{C}$, could deposit banded $\mathrm{Ca}$-carbonate veins close to the surface, resulting in lower $\delta^{13} \mathrm{C}$ values, as we observe inV1 and V2 from PAM1 and ET3 samples. In contrast, $\delta^{13} \mathrm{C}_{\mathrm{CO} 2}$ calculations for $\mathrm{V} 3$ and PAM13 overlap with the $\delta^{13} \mathrm{C}_{\mathrm{CO} 2}$ values recorded in the northern part of the Larderello geothermal area, where the study area is located (Figure 1). Here, most of the gas emissions are characterized by $\delta^{13} \mathrm{C}_{\mathrm{CO} 2}$ ranging between $-7 \%$ and $-4 \%$ o (V-PDB), with few values lower than $-7 \%$ o (V-PDB), [115]. These values have been interpreted as the results of primary $\mathrm{CO}_{2}$ rising up from the mantle [116] or, alternatively, a mixing between isotopically heavy and light $\mathrm{CO}_{2}$ coming from the geothermal reservoir and organic sediments produced in the Neogene basins, respectively [124]. Therefore, V3 and PAM13 veins could be the result of a one-stage deposition from a fluid directly coming from depth.

Temperature of the hydrothermal fluid circulated within the main fissure of the travertine ridge was determined by clumped isotope thermometry to be $67^{\circ} \mathrm{C} \pm 6^{\circ} \mathrm{C}$ for the band analyzed at the University of Washington and $68^{\circ} \mathrm{C} \pm 4^{\circ} \mathrm{C}$ and $85^{\circ} \mathrm{C} \pm 3^{\circ} \mathrm{C}$ for the bands analyzed at ATOMKI. These values exceed the temperature of the modern fluids $\left(22^{\circ} \mathrm{C}\right.$, $[11,125])$ of the active thermal spring located in the Il Palagio area (Figure 2), confirming that the temperature of the fluid has changed through time.

We calculated the $\delta^{18} \mathrm{O}_{\mathrm{w}}$ values from the measured carbonate $\delta^{18} \mathrm{O}$ values, using the clumped isotope derived temperature for IA1 and the Kim et al. [126] and Chacko and Deines [127] equations for the temperature dependence of aragonite-water oxygen isotope fractionation, assuming equilibrium conditions during aragonite deposition. The results using the two equations are indistinguishable (2.6\%o $\mathrm{V}$-SMOW). The $\delta^{18} \mathrm{O}_{\mathrm{w}}$ values are out of the range of present-day regional rainwater $\delta^{18} \mathrm{O}_{\mathrm{w}}$ values $\left(\delta^{18} \mathrm{O}_{\mathrm{w}}=-7\right.$ to $-6 \%$ ) that feed the shallow hydrothermal system of southern Tuscany $[11,124]$. This result could suggest that (a) the fluids were possibly influenced by magmatic source water (in Larderello geothermal field $\delta^{18} \mathrm{O}$ of magmatic waters ranges from $+3 \%$ o to $+8 \%$, in [128]), causing a heavier composition of the $\mathrm{O}$ isotopes, or that (b) fossil meteoric water extensively interacted with the Tuscan Nappe carbonate rocks that are characterized by a positive signature of $\delta^{18} \mathrm{O}(\sim+25 \%$, [129]).

\subsection{The Tectonic Control on the Fluid Flow. Mesostructural} data indicate that the fault-slip surfaces and damage zones of the two main NE- and NW-trending fault systems are often characterized by Fe-hydroxides and banded Cacarbonate veins (Figure 3). This observation implies that both systems channeled geothermal fluids. Comparable evidence comes from the field mapping (Figure 2), which indicates that both the fossil and active travertine deposition is mainly located along the NW-striking faults, at the intersection with the NE-striking major faults. Thus, we conclude that in the study area, permeability and hydraulic conductivity of deep fluids are controlled by fractures.

In this view, it is noteworthy to underline that the main fissure ridge (from which the analyzed samples were collected) displays a NW trend, parallel to the main fault zones characterizing the whole study area. Furthermore, in the proximity of Iano village, travertine bodies are associated 
with the interplay between NE- and NW-trending faults. Similar trends, parallel to the main NW-trending faults, characterize the minor banded Ca-carbonate veins cutting both the travertine bodies and units forming the travertine substratum. The main banded Ca-carbonate vein developed in the central part of the $\mathrm{NW}$-trending fissure ridge (Figure 6(a)) suggests that this travertine deposit developed along a permeable sector of a NW-striking fault. At least part of the fault activity (from $172 \pm 3$ to $21.2 \pm 0.1 \mathrm{ka}$ ) is recorded by the banded $\mathrm{Ca}$-carbonate veins development. Similarly, a small number of thin veins are NE-oriented, such as vein V2 from PAM1 and ET3 samples. This superposed veining (V1, V2, and V3) is indicative of repeated deformation episodes, followed by progressive fracture sealing by $\mathrm{Ca}-$ carbonate deposition.

Kinematic indicators on the NE-trending faults indicate strike-slip movements. This is significant since, in agreement with Sibson [130], the intermediate axis attitude indicates the preferential direction of fluid flow. Thus, an oblique, near vertical, intermediate axis can explain the up flow migration of deep fluids and therefore the occurrence of $\mathrm{CO}_{2}$ of mantle origin (Figure 4). This suggests that the NE-striking faultzones play a role in channeling upward fluid migration, as already suggested for the Larderello area [68].

Interaction with NW-trending faults is then significant for two related reasons: (a) the intersection of NW- and with NE-trending faults increases fracture distribution, promoting hydraulic conductivity and (b) the intermediate axis of the $\mathrm{NW}$-trending faults being close to horizontal enables, geothermal fluids to flow laterally, interacting with the host rocks (hence, enriching their content in ${ }^{18} \mathrm{O}$, for instance), and arriving to the surface when the dilatation component of the normal fault is efficient.

This framework of crosscutting relationships was also envisaged in similar geological contexts [19, 75, 131-133] and proposed to determine alignment of thermal springs $[19,134-138]$. Our findings thus reenforce the concept that travertine deposits record the tectonic activity through time in geothermal areas $[3,7,8,12,13,17,18,20,22,23,29$, 64, 139-142].

5.3. Factors Influencing Fluid Property Variation. Deformation of the crust in geothermal areas promotes the mobilization of large volumes of saline and $\mathrm{CO}_{2}$-rich waters $[8,11$, 143]. These fluids are involved in fault zones during sudden strain that can promote $\mathrm{CO}_{2}$ degassing and consequent carbonate precipitation, especially within fractures that act as conduits $[7,13,17,34,144]$. Carbonate precipitation, in terms of mineralogy and isotopic composition, is the result of combined effects such as fluid composition, degassing rate, $\mathrm{pH}$ variation and fluid temperature. As a consequence, each mineralogical and isotopic variation recorded by the banded Ca-carbonate veins can potentially reveal important tectonic episodes.

Our samples show repeated changes of the mineralogical composition and isotopic signatures, which we interpret in this context.

Vein V1 of the PAM1 sample (vein crossing the flank of the ridge, Figures $7(\mathrm{~b})$ and $8(\mathrm{a})$ ) is characterized by the alter- nation of ( $\mathrm{Sr}$ )-aragonite and calcite bands (see Figures $7(\mathrm{~g})$ and $7(\mathrm{~h})$ ), implying that the depositional conditions (fluid composition, temperature and $\mathrm{pCO}_{2}$ ) changed through time. On the other hand, vein V3 and PAM13 (vein filling the central part of the ridge, Figure 6(b)) are completely composed of bands formed by acicular aragonite crystals.

Several studies were aimed at defining the main factors that favor the aragonite formation instead of calcite in depositing carbonate. The most significant factors for aragonite formation are (i) the high temperature of water [145-147] and (ii) the high Mg content [145, 148, 149]; nevertheless, several studies underlined that other factors have to be taken into consideration. Malesani and Vannucci [150] proposed that high Sr levels also favor aragonite deposition. The high $\mathrm{Sr}$ concentration in the fluid plays an essential role in modifying the surface energy term, therefore favoring $\mathrm{Sr}$ in the aragonite lattice [151]. Lippman [147] suggests that aragonite precipitates preferentially when the rate of $\mathrm{CO}_{2}$ degassing is the greatest, implying that the kinetic effect controls the mineralogy. Similar conclusions were reached by Duchi et al. [125] who investigated springs depositing travertine characterized by different temperature and geochemical features. They argued that in addition to the role of the temperature and $\mathrm{Mg}$ content, the partial pressure of $\mathrm{CO}_{2}$ can contribute to the deposition of aragonite instead of calcite. This is due to the rapid $\mathrm{CO}_{2}$ degassing inducing high level of supersaturation and $\mathrm{pH}$ increase, both triggering the rapid deposition of aragonite (Duchi et al. [125]). Therefore, aragonite deposition can be favored by (i) thermal springs characterized by lower temperatures (below $30^{\circ} \mathrm{C},[145,147]$ ) and $\mathrm{pCO}_{2}$ significantly higher than the atmospheric $\mathrm{pCO}_{2}$ (which is the case of the study area; Duchi et al. [125]; [11]) or (ii) thermal springs characterized by higher temperature (above $30^{\circ} \mathrm{C}$; [5]).

The rate and amount of $\mathrm{CO}_{2}$ discharge can be influenced by the tectonic activity $[15,29,142,152]$ and/or climatic variations $[8,32,153]$. Climate can control the amount of $\mathrm{CO}_{2}$ dissolved in the water (cf. [8]). However, considering the fact that the parent fluids we analyzed came from hypogean conduits (faults and fractures) and reached the surface (i.e., fluids with $\mathrm{pCO}_{2}$ equilibrating with the $\mathrm{pCO}_{2}$ of the atmosphere), other factors are likely needed to explain the (sudden) $\mathrm{CO}_{2}$ degassing. In our opinion, pulses of the tectonic activity are reasonable factors. In particular, for samples PAM1 and ET3, it can be assumed that the high $\mathrm{CO}_{2}$ degassing rate could have caused mineralogical differentiation between calcite and aragonite. This implies that the $\mathrm{CO}_{2}$ partial pressure has changed through time. This is supported by the stable isotope data of our banded Ca-carbonate veins (Figure 11(a)) which display larger $\delta^{13} \mathrm{C}$ variation than $\delta^{18} \mathrm{O}$. In particular, aragonite bands are characterized by the highest $\delta^{13} \mathrm{C}$ values, suggesting that fast $\mathrm{CO}_{2}$ degassing has strongly influenced the deposition of these bands, causing disequilibrium due to the kinetic effect. In addition, $\delta^{18} \mathrm{O}$ and $\delta^{13} \mathrm{C}$ values correlate $\left(R^{2}=0.85\right.$, Figure $\left.11(\mathrm{~b})\right)$, implying a deposition under disequilibrium conditions. In fact, during degassing, isotopically light carbon dioxide preferentially escapes and, as a consequence, the ${ }^{13} \mathrm{C}$ and ${ }^{18} \mathrm{O}$ contents in depositing $\mathrm{CaCO}_{3}$ increase in the same direction $[5,7,8,34,115,154-156]$. For this reason, a positive 


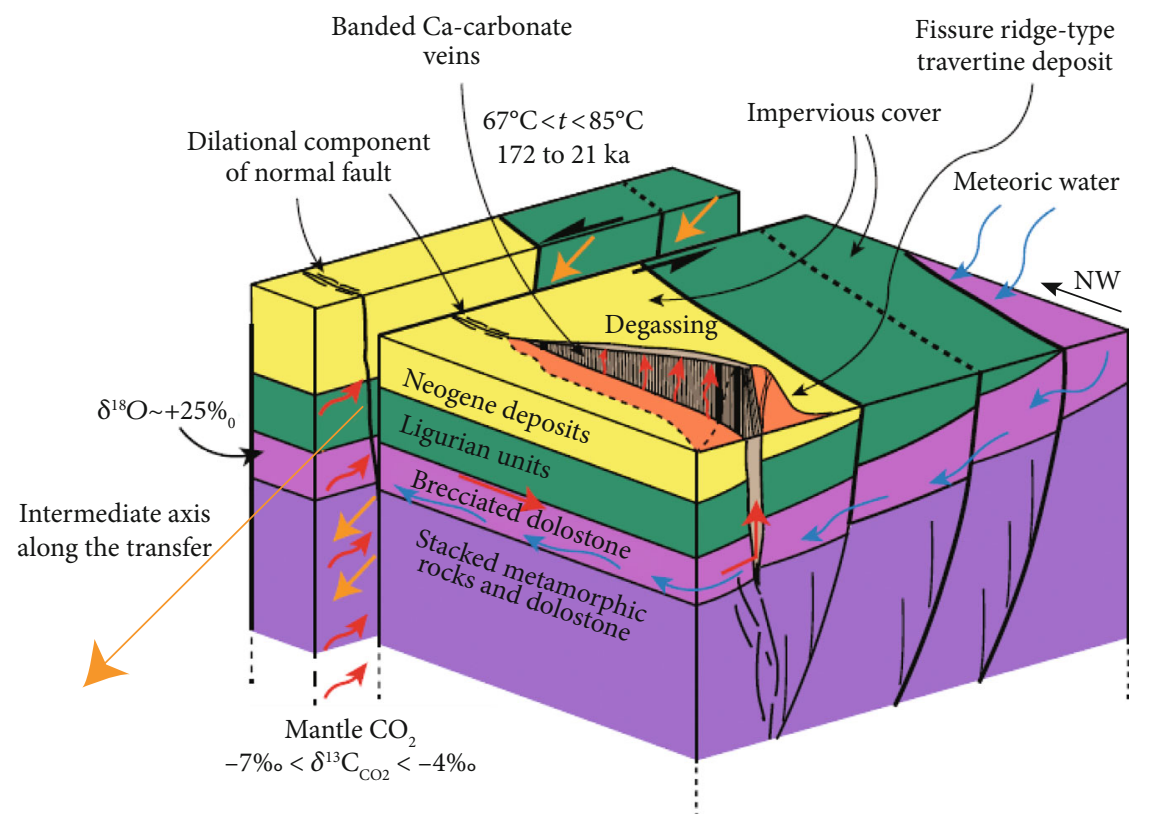

Figure 12: Not to scale cartoon showing the conceptual model of the hydrothermal fluid circulation in the Iano area. Meteoric waters infiltrated at depth through dolostone and limestone forming the Late Triassic evaporite level that is exposed in the eastern basin shoulder. The heated fluids interacted with the evaporite rocks, increase their $\delta^{18} \mathrm{O}$, and mixed with mantle derived fluids channeled along the main fault zones. The same fault zones (mainly N120 striking) channeled the fluids up to the surface, where thermal springs, active since late Pleistocene, are depositing travertine bodies. Travertine fissure ridges and mounds are the main tectonometamorphic features occurring in the Iano area.

correlation is recorded. Furthermore, the texture of these crystals shows ending faces with pointed terminations (cfr. 4.3.3), implying that some crystals grew faster than others. Therefore, fast degassing could have increased the depositional rate of aragonite crystals.

In contrast, isotope values of calcite crystals of sample PAM1 do not show any correlation and $\delta^{13} \mathrm{C}$ values are all around $0 \%$, with some values slightly negative. This evidence implies that the isotopic composition of fluids remained constant during calcite crystals formation, and (possibly) crystals formed under isotopic equilibrium. The texture of calcite crystals validate this hypothesis because crystals enlarge in the growth direction and their terminations are characterized by pointed curved faces, suggesting that the crystals grew slowly and had the time to develop.

Therefore, if $\mathrm{CO}_{2}$ degassing rate was a factor, it would imply that the veins record $\mathrm{CO}_{2}$ partial pressure changes through time.

In contrast, sample PAM13 is completely made up of aragonite (Figure 9(a)), and stable isotope values do not show any correlation (Figure 11(a)). Clumped isotopes highlight a depositional temperature between $67^{\circ}$ and $85^{\circ} \mathrm{C}$ (Table 5), suggesting that temperature played a more important role than $\mathrm{pCO}_{2}$ in depositing aragonite, an interpretation that is also supported by the lack of correlation between stable isotope values.

Finally, we discuss the tree-shaped black structures described for the vein V1 (Figures 7(d) and 8(a)). These structures have never been described in banded $\mathrm{Ca}$ carbonate veins; they have only been documented for travertine deposits [103-105, 157, 158] and speleothems [159].
From a mineralogical point of view, the black tree-shaped structures contain manganese dioxides, which are based on $\left[\mathrm{MnO}_{6}\right]$ octahedra units linked in chains to form a framework structure containing monodimensional tunnels with specific sizes. Tunnels can accommodate different chemical species, such as $\mathrm{Mg}, \mathrm{Cu}, \mathrm{Ni}, \mathrm{Co}$, and $\mathrm{Fe}$ in their ionic state [105]. For this reason, in some cases, high percentages of $\mathrm{Ni}$ ( $5.01 \%$ on average) have been measured. The Raman results suggest that the black tree-shaped structures consist of todorokite, although the possible presence of cryptomelane or hollandite cannot be ruled out. Indeed, our data are in good agreement with Bernardini et al. [109] who report for todorokite a broad and strong band at $630 \mathrm{~cm}^{-1}$ with shoulders at $\sim 507$ and $575 \mathrm{~cm}^{-1}$. However, the possible occurrence of cryptomelame or hollandite cannot be ruled out. Although spectroscopic data from the literature are conflicting, some recent studies [109] report for cryptomelane a position of the strong band centered between 623 and $655 \mathrm{~cm}^{-1}$ and a shoulder at $\sim 580 \mathrm{~cm}^{-1}$. Similar positions are reported for hollandite.

In speleothems and travertine deposits, tree-shaped structures are strictly associated with bacterial activity inducing the precipitation of Mn-oxides. Precipitation produce aggregates with high $\mathrm{Mn}$ concentration (Mn-oxides), even from water with low $\mathrm{Mn}^{2+}$ concentration (parts per million range, [103]). This process was very likely promoted by specific environmental parameters: in surficial flowing waters, $\mathrm{pH}$ changes are favored by temperature and $\mathrm{CO}_{2}$ degassing rate variations. In contrast, these factors cannot abruptly change in deep conduits. As a consequence, the occurrence of Mn-rich deposits is indicative of changes of the 
hydrothermal fluid conditions. Changes in $\mathrm{pH}$ within the circulating waters suggest fluid compositional variation. Values of $\mathrm{pH}$ above 5 [103] and oxidizing environments promote the precipitation of Mn-oxides [160]. In the case of Iano, these tree-shaped black structures are characterized by our lowest measured $\delta^{13} \mathrm{C}$ values (-1.2\%o and $-0.4 \%$ V-PDB), suggesting significant mixing between hydrothermal and meteoric waters. In these conditions, microorganisms could thrive, locally modifying the $\mathrm{pH}$ conditions and discharging metabolic products able to oxidize $\mathrm{Mn}^{2+}[105,161]$. As long as these conditions persist, Mn-oxides continue to deposit due to microorganism metabolic processes. As a consequence, tree-shaped black structures are indicative of a lowtemperature fluid depleted in $\mathrm{CO}_{2}$. These conditions can develop after rapid $\mathrm{CO}_{2}$ degassing in waters that remain in surficial levels, favoring mixing with meteoric waters. These structures are absent in the banded $\mathrm{Ca}$-carbonate veins filling the central fissure of the ridge, suggesting that the fluids in the central fissure maintained high temperature through time, favoring aragonite deposition and did not interact with surficial waters.

In this view, the tree-shaped black structures can suggest a phase of transition after a fast $\mathrm{CO}_{2}$ degassing event, during which hydrothermal waters mix with more surficial ones, causing temperature decrease. Thus, tree-shaped black structures can be useful indicators for a stasis phase of the hydrothermal fluid circulation and a mixing of hydrothermal and meteoric waters.

\section{Conclusions}

Banded Ca-carbonate veins represent key tools for decoding variations in geothermal fluid properties though time. Veins forming in the Iano travertine depositional system preserve compositional fluctuations of the geothermal fluids (red arrows in Figure 12) that flowed from the deep reservoir up to the surface, along fault zones (Figure 12). These fault zones are characterized by changes in their kinematics, which combined with their orthogonal arrays, and gave rise to localized permeable volumes able to channel deep fluids up to the surface, therefore mixing with shallow (i.e., meteoric) origin fluids (blue arrows in Figure 12). Fluids move following the intermediate axis along the transfer faults indicated by orange arrows in Figure 12. Our record started in the middle Pleistocene, where the fault permeability induced the geothermal fluids to flow at the surface. From $172 \pm 3 \mathrm{ka}$ until (at least) $27.1 \pm 0.1 \mathrm{ka}$, the circulating fluids deposited banded Ca-carbonate veins following a multistep process. During its rise along faults and fractures, the fluid interacted with carbonate deposits, becoming enriched in $\delta^{18} \mathrm{O}$ (Figure 12); as a consequence, the stable isotopic composition of the fluid changed. Banded Ca-carbonate veins at different depths developed within faults and fractures, probably due to pulses of tectonic activity. Starting by at least $27.1 \pm 0.1 \mathrm{ka}$, the fluid preserved the initial stable isotope imprint, from depth to the surface, following a one-stage deposition process.

Travertine deposits mostly formed from thermal springs aligned along NW-trending faults and at their intersection with NE-trending faults. Most of the banded-Ca carbonate veins follow the NW direction, even if in some cases, some very thin veins cut the previously deposited veins in the NE direction.

Our observations from the Iano area represent the first documented tree-shaped black structures, made up by $\mathrm{Mn}$ oxides, in banded Ca-carbonate veins. The mineralogy is mostly likely todorokite and their deposition can be indicative of a stasis phase following a rapid $\mathrm{CO}_{2}$ degassing that favors the mixing of deep origin hydrothermal fluids with shallow meteoric waters. As a consequence, fluid temperature and $\mathrm{CO}_{2}$ content decrease, allowing the development of microbial communities in oxidizing and acid environment $(\mathrm{pH}>5)$. Thus, Mn-rich deposits could have a key role in decoding periods of low fluid flux and mixing with more surficial waters.

\section{Data Availability}

The data support the results of this study and are reported in the Tables.

\section{Conflicts of Interest}

The authors declare that there is no conflict of interest regarding the publication of this paper.

\section{Acknowledgments}

S. Kele was supported by the National Research, Development, and Innovation Office in Hungary (NKFI Alap, KH125584 project) and by the European Union and the State of Hungary, cofinanced by the European Regional Development Fund in the project of GINOP-2.3.2-15-2016-00009 "ICER." A. Brogi and E. Capezzuoli were supported by FFABR grants (financial support for the base-research activity) from the MIUR (Ministry of Education and University). $\mathrm{U}$-Th dating was supported by grants from the Science Vanguard Research Program of the Ministry of Science and Technology (MOST) (107-2119-M-002-051, 108-2119-M002-012 to C.-C.S.), the National Taiwan University (105R7625 to C.-C.S.), and the Higher Education Sprout Project of the Ministry of Education, Taiwan ROC (108L901001 to C.-C.S.). K. Huntington acknowledges support from the U.S. National Science Foundation (EAR-1156134). The research work has been supported by the MIUR-Italy Dipartimenti di Eccellenza (ARTICOLO 1, COMMI 314-337 LEGGE 232/2016), by the University of Bari (Italy), and by the CNR-National Research Council (Italy). Comments and suggestions by the reviewers helped us to improve the original version of the manuscript.

\section{Supplementary Materials}

The carbonate clumped isotope values measured at ATOMKI (Institute for Nuclear Research, Debrecen, Hungary) were performed using Thermo Scientific Kiel IV Automatic Carbonate Device coupled to a Thermo Scientific MAT253 Plus isotope ratio mass spectrometer (as previously said in Section 3.2). The normalization standards used were ETH1, ETH2, and 
ETH3 coupled with IAEA-C2, used as quality control sample with the values reported in Table S1 [91]. $\Delta_{47}$ is reported in the CDES (carbon-dioxide equivalent scale) [91], using an acid fractionation factor of $+0.066 \%$ o to set down data generated with $70^{\circ} \mathrm{C}$ acid digestion on the $25^{\circ} \mathrm{C}$ digestion scale. Easotope application [95] was used for data evaluation, using $\mathrm{CO}_{2}$ clumped ETH PBL replicate analyses method and Brand parameters (Table S2). (Supplementary Materials)

\section{References}

[1] E. Barbier, "Geothermal energy and current status: an overview," Renewable and Sustainable Energy Reviews, vol. 6, pp. 3-65, 2002.

[2] H. S. Chafetz, P. F. Rush, and N. M. Utech, "Microenvironmental controls on mineralogy and habit of $\mathrm{CaCO}_{3}$ precipitates: an example from an active travertine system," Sedimentology, vol. 38, no. 1, pp. 107-126, 1991.

[3] P. L. Hancock, R. M. L. Chalmers, E. Altunel, and Z. Çakır, "Travitonics: using travertines in active fault studies," Journal of Structural Geology, vol. 21, no. 8-9, pp. 903-916, 1999.

[4] S. Kele, M. Özkul, I. Fórizs et al., "Stable isotope geochemical study of Pamukkale travertines: New evidences of lowtemperature non-equilibrium calcite-water fractionation," Sedimentary Geology, vol. 238, no. 1-2, pp. 191-212, 2011.

[5] A. Pentecost, Travertine, Springer, Berlin, 2005.

[6] R. W. Renaut and B. Jones, "Controls on aragonite and calcite precipitation in hot spring travertines at Chemurkeu, Lake Bogoria, Kenya," Canadian Journal of Earth Sciences, vol. 34, no. 6, pp. 801-818, 1997.

[7] I. T. Uysal, Y. Feng, J.-X. Zhao et al., "U-series dating and geochemical tracing of late Quaternary travertine in co- seismic fissures," Earth and Planetary Science Letters, vol. 257, no. 3-4, pp. 450-462, 2007.

[8] I. T. Uysal, Y. Feng, J.-X. Zhao, V. Isik, P. Nuriel, and S. D. Golding, "Hydrothermal $\mathrm{CO}_{2}$ degassing in seismically active zones during the late Quaternary," Chemical Geology, vol. 265, no. 3-4, pp. 442-454, 2009.

[9] D. Curewitz and J. A. Karson, "Structural settings of hydrothermal outflow: fracture permeability maintained by fault propagation and interaction," Journal of Volcanology and Geothermal Research, vol. 79, no. 3-4, pp. 149-168, 1997.

[10] E. Capezzuoli, A. Gandin, and H. M. Pedley, "Travertine and Calcareous tufa in Tuscany (Central Italy)," Field Trip Guide Book, Pre-conference trip FT7, 27th IAS Meeting of Sedimentology, V. Pascucci and S. Andreucci, Eds., pp. 129-158, 2009.

[11] A. Minissale, "Origin, transport and discharge of $\mathrm{CO}_{2}$ in Central Italy,” Earth-Science Reviews, vol. 66, no. 1-2, pp. 89-141, 2004.

[12] A. Brogi and E. Capezzuoli, "Earthquake impact on fissureridge type travertine deposition," Geological Magazine, vol. 151, no. 6, pp. 1135-1143, 2014.

[13] V. Karabacak, I. T. Uysal, H. Mutlu et al., "Are U-Th dates correlated with historical records of earthquakes? Constraints from co-seismic carbonate veins within the North Anatolian Fault Zone," Tectonics, vol. 38, no. 7, pp. 24312448, 2019.

[14] I. T. Uysal, Y. Feng, J.-X. Zhao et al., "Seismic cycles recorded in late Quaternary calcite veins: geochronological, geochemical and microstructural evidence," Earth and Planetary Science Letters, vol. 303, no. 1-2, pp. 84-96, 2011.
[15] R. T. Williams, L. B. Goodwin, W. D. Sharp, and P. S. Mozley, "Reading a 400,000-year record of earthquake frequency for an intraplate fault," Proceedings of the National Academy of Sciences of the United States of America, vol. 114, no. 19, pp. 4893-4898, 2017.

[16] E. Altunel, "Pamukkale travertenlerinin morfolojik özellikleri, yaşları ve neotektonik önemleri," Mineral Research and Exploration Institute of Turkey, Bulletin of the Mineral Research and Exploration, vol. 118, pp. 47-65, 1996.

[17] E. Altunel and V. Karabacak, "Determination of horizontal extension from fissure-ridge travertines: a case study from the Denizli Basin, southwestern Turkey," Geodinamica Acta, vol. 18, pp. 333-342, 2012.

[18] A. Brogi and E. Capezzuoli, "Travertine deposition and faulting: the fault-related travertine fissure-ridge at Terme S. Giovanni, Rapolano Terme (Italy)," International Journal of Earth Sciences, vol. 98, no. 4, pp. 931-947, 2009.

[19] A. Brogi, D. Liotta, E. Capezzuoli et al., "Travertine deposits constraining transfer zone neotectonics in geothermal areas: an example from the inner Northern Apennines (Bagno Vignoni-Val d'Orcia area, Italy)," Geothermics, vol. 85, p. 101763, 2020.

[20] Z. Çakir, "Along-strike discontinuity of active normal faults and its influence on quaternary travertine deposition: examples from Western Turkey," Turkish Journal of Earth Sciences, vol. 8, pp. 67-80, 1999.

[21] R. J. Hansman, R. Albert, A. Gerdes, and U. Ring, "Absolute ages of multiple generations of brittle structures by $\mathrm{U}-\mathrm{Pb}$ dating of calcite," Geology, vol. 46, no. 3, pp. 207-210, 2018.

[22] E. Altunel and P. L. Hancock, "Active fissuring and faulting in quaternary travertines at Pamukkale, western Turkey," Zeitschrift für Geomorphologie, vol. 94, pp. 285-302, 1993.

[23] E. Altunel and P. L. Hancock, "Morphology and structural setting of Quaternary travertines at Pamukkale, Turkey," Geological Journal, vol. 28, pp. 335-346, 1993.

[24] A. Brogi, E. Capezzuoli, R. Aqué, M. Branca, and M. Voltaggio, "Studying travertines for neotectonics investigations: Middle-Late Pleistocene syn-tectonic travertine deposition at Serre di Rapolano (Northern Apennines, Italy)," Geologische Rundschau, vol. 99, no. 6, pp. 13831398, 2010.

[25] A. Brogi, E. Capezzuoli, E. Buracchi, and M. Branca, “Tectonic control on travertine and calcareous tufa deposition in a low-temperature geothermal system (Sarteano, Central Italy)," Journal of the Geological Society, London, vol. 169, no. 4, pp. 461-476, 2012.

[26] K. E. Bargar, "Geology and thermal history of mammoth hot springs, Yellowstone National Park, Wyoming," United States Geological Survey Bulletin, vol. 1444, pp. 1-55, 1978.

[27] G. Berardi, G. Vignaroli, A. Billi et al., "Growth of a Pleistocene giant carbonate vein and nearby thermogene travertine deposits at Semproniano, southern Tuscany, Italy: estimate of $\mathrm{CO}_{2}$ leakage," Tectonophysics, vol. 690, pp. 219-239, 2016.

[28] A. Brogi, E. Capezzuoli, M. C. Alçiçek, and A. Gandin, "Evolution of a fault-controlled fissure-ridge type travertine deposit in the western Anatolia extensional province: the Çukurbağ fissure-ridge (Pamukkale, Turkey)," Journal of Geological Society, vol. 171, no. 3, pp. 425-441, 2014.

[29] A. Brogi, M. C. Alçiçek, C. C. Yalçıner et al., "Hydrothermal fluids circulation and travertine deposition in an active 
tectonic setting: insights from the Kamara geothermal area (western Anatolia, Turkey)," Tectonophysics, vol. 680, pp. 211-232, 2016.

[30] L. de Filippis, C. Faccenna, A. Billi et al., "Growth of fissure ridge travertines from geothermal springs of Denizli basin, western Turkey," Geological Society of America Bulletin, vol. 124, no. 9-10, pp. 1629-1645, 2012.

[31] B. L. Mesci, H. Gursoy, and O. Tatar, "The evolution of travertine masses in the Sivas area (Central Turkey) and their relationships to active tectonics," Turkish Journal of Earth Sciences, vol. 17, pp. 219-240, 2008.

[32] C. Faccenna, M. Soligo, A. Billi et al., "Late Pleistocene depositional cycles of the lapis Tiburtinus travertine (Tivoli, Central Italy): possible influence of climate and fault activity," Global and Planetary Change, vol. 63, no. 4, pp. 299-308, 2008.

[33] I. Seghedi and C. Helvac1, "Early Miocene Kırka-Phrigian Caldera, western Turkey (Eskişehir province), preliminary volcanology, age and geochemistry data," Journal of Volcanology and Geothermal Research, vol. 327, pp. 503-519, 2016.

[34] E. Capezzuoli, G. Ruggieri, V. Rimondi et al., "Calcite veining and feeding conduits in a hydrothermal system: Insights from a natural section across the Pleistocene Golemezli travertine depositional system (western Anatolia, Turkey)," Sedimentary Geology, vol. 364, pp. 180-203, 2018.

[35] N. Janssens, E. Capezzuoli, H. Claes et al., "Fossil travertine system and its palaeofluid provenance, migration and evolution through time: example from the geothermal area of Acquasanta Terme (Central Italy)," Sedimentary Geology, vol. 398, article 105580, 2020.

[36] F. Batini, A. Brogi, A. Lazzarotto, D. Liotta, and E. Pandeli, "Geological features of Larderello-Travale and Mt. Amiata geothermal areas (southern Tuscany, Italy)," Episodes, vol. 26, no. 3, pp. 239-244, 2003.

[37] A. Bossio, A. Costantini, A. Lazzarotto et al., "Rassegna delle conoscenze sulla stratigrafia del Neoautoctono Toscano," Memorie della Societa Geologica Italiana, vol. 49, pp. 17-98, 1993.

[38] R. Mazzanti, "Geologia della zona di Pomarance-Larderello (Prov. di Pisa)," Memorie della Societa Geologica Italiana, vol. 5, pp. 105-138, 1966.

[39] G. Molli, "Northern Apennine-Corsica orogenic system: an updated overview," Geological Society, London, Special Publications, vol. 298, no. 1, pp. 413-442, 2008.

[40] G. B. Vai and I. P. Martini, Anatomy of an orogen: the Apennines and Adjacent Mediterranean Basins, Kluwer Academic Publishers, 2001.

[41] L. Carmignani, F. A. Decandia, P. L. Fantozzi, A. Lazzarotto, D. Liotta, and M. Meccheri, "Tertiary extensional tectonics in Tuscany (northern Apennines, Italy)," Tectonophysics, vol. 238, no. 1-4, pp. 295-315, 1994.

[42] A. Brogi and G. Giorgetti, "The tectono-metamorphic record of the Tuscan Nappe from the Colline Metallifere region (northern Apennines, Italy)," Italian Journal of Geosciences, vol. 129, pp. 177-187, 2010.

[43] A. Brogi and G. Giorgetti, "Tectono-metamorphic evolution of the siliciclastic units in the Middle Tuscan Range (inner Northern Apennines): Mg-carpholite bearing quartz veins related to syn-metamorphic syn-orogenic foliation," Tectonophysics, vol. 526-529, pp. 167-184, 2012.
[44] E. Pandeli, G. Bertini, and P. Castellucci, "The tectonic wedges complex of the Larderello area (southern Tuscany, Italy)," Bollettino- Societa Geologica Italiana, vol. 110, pp. 621-629, 1991.

[45] F. Rossetti, C. Faccenna, L. Jolivet, B. Goffé, and R. Funiciello, "Structural signature and exhumation P-T-t paths of the blueschist units exposed in the interior of the northern Apennine chain, tectonic implications," Bollettino della Societa Geologica Italiana, vol. 1, pp. 829-842, 2002.

[46] M. R. Barchi, "The Neogene-Quaternary evolution of the Northern Apennines: crustal structure, style of deformation and seismicity," Journal of the Virtual Explorer, vol. 36, 2010.

[47] M. Boccaletti, P. Elter, and G. Guazzone, "Plate tectonic models for the development of the western Alps and northern Apennines," Nature Physical Science, vol. 234, no. 49, pp. 108-111, 1971.

[48] L. Carmignani, F. A. Decandia, L. Disperati et al., "Relationships between the Tertiary structural evolution of the Sardinia-Corsica-Provençal domain and the northern Apennines," Terra Nova, vol. 7, no. 2, pp. 128-137, 1995.

[49] C. Doglioni, "A proposal for the kinematic modelling of Wdipping subductions - possible applications to the Tyrrhenian-Apennines system," Terra Nova, vol. 3, no. 4, pp. 423-434, 1991.

[50] G. Lavecchia, "The Tyrrhenian-Apennines system: structural setting and seismotectogenesis," Tectonophysics, vol. 147, no. 3-4, pp. 263-296, 1988.

[51] D. Liotta, L. Cernobori, and R. Nicolich, "Restricted rifting and its coexistence with compressional structures: results from the CROP 3 traverse (northern Apennines, Italy)," Terra Nova, vol. 10, no. 1, pp. 16-20, 1998.

[52] I. P. Martini and M. Sagri, "Tectono-sedimentary characteristics and the genesis of the recent magmatism of southern Tuscany and northern Latium," Per. Mineral., vol. 56, pp. 157-172, 1993.

[53] E. Patacca, R. Sartori, and P. Scandone, "Tyrrhenian basin and Apenninic arcs: kinematic relations since late Tortonian times," Memorie della Societa Geologica Italiana, vol. 45, pp. 425-451, 1990.

[54] R. Bartole, "The north-Tyrrhenian-northern Apennines post-collisional system: constraints for a geodynamic model," Terra Nova, vol. 1, pp. 7-30, 1995.

[55] C. Brunet, P. Monié, L. Jolivet, and J. P. cadet, "migration of compression and extension in the Tyrrhenian Sea, insights from ${ }^{40} \mathrm{Ar} /{ }^{39} \mathrm{Ar}$ ages on micas along a transect from Corsica to Tuscany," Tectonophysics, vol. 321, no. 1, pp. 127-155, 2000.

[56] L. Jolivet, R. Dubois, R. Fournier, B. Goffé, A. Michard, and C. Jourdan, "Ductile extension in alpine Corsica," Geology, vol. 18, no. 10, pp. 1007-1010, 1990.

[57] V. Pascucci, S. Merlini, and I. P. Martini, "Seismic stratigraphy of the Miocene-Pleistocene sedimentary basins of the northern Tyrrhenian Sea and western Tuscany (Italy)," Basin Research, vol. 11, no. 4, pp. 337-356, 1999.

[58] F. Storti, “Tectonics of the Punta Bianca promontory: insights for the evolution of the northern Apennines-northern Tyrrhenian Sea basin," Tectonics, vol. 14, no. 4, pp. 832-847, 1995.

[59] R. Di Stefano, C. Chiarabba, L. Chiaraluce et al., "Fault zone properties affecting the rupture evolution of the 2009 
$\left(\mathrm{M}_{\mathrm{w}} 6.1\right)$ L'Aquila earthquake (Central Italy): insights from seismic tomography," Geophysical Research Letters, vol. 38, no. 10, p. 110310, 2011.

[60] A. Brogi, "Bowl-shaped basin related to low-angle detachment during continental extension: the case of the controversial Neogene Siena Basin (Central Italy, northern Apennines)," Tectonophysics, vol. 499, pp. 131-148, 2011.

[61] A. Brogi and D. Liotta, "Highly extended terrains, lateral segmentation of the substratum, and basin development: the Middle-Late Miocene Radicondoli Basin (inner northern Apennines, Italy),” Tectonics, vol. 27, article TC5002, 2008.

[62] R. D. Dallmeyer and D. Liotta, "Extension, uplift of rocks and cooling ages in thinned crustal provinces: the Larderello geothermal area (inner northern Apennines, Italy)," Geological Magazine, vol. 135, no. 2, pp. 193-202, 1998.

[63] F. A. Decandia, A. Lazzarotto, and D. Liotta, "La "Serie ridotta" nel quadro dell'evoluzione geologica della Toscana meridionale," Memorie della Società Geologica Italiana, vol. 49, pp. 181-190, 1993.

[64] A. Brogi, "Assetto geologico del nucleo di Falda Toscana affiorante nel settore occidentale del Monte Amiata (Appennino Settentrionale): strutture pre- e sin-collisionali relitte preservate durante lo sviluppo della tettonica distensiva post-collisionale," Bollettino della Società Geologica Italiana, vol. 123, pp. 443-461, 2004.

[65] A. Brogi, A. Lazzarotto, D. Liotta, and G. Ranalli, "Crustal structures in the geothermal areas of southern Tuscany (Italy): Insights from the CROP 18 deep seismic reflection lines," Journal of Volcanology and Geothermal Research, vol. 148, no. 1-2, pp. 60-80, 2005.

[66] A. Brogi, F. Fidolini, and D. Liotta, "Tectonic and sedimentary evolution of the Upper Valdarno Basin: new insights from the lacustrine S. Barbara Basin," Italian Journal of Geoscience, vol. 132, pp. 81-97, 2013.

[67] D. Liotta, G. Ruggieri, A. Brogi, P. Fulignati, A. Dini, and I. Nardini, "Migration of geothermal fluids in extensional terrains: the ore deposits of the Boccheggiano-Montieri area (southern Tuscany, Italy)," International Journal of Earth Sciences, vol. 99, no. 3, pp. 623-644, 2010.

[68] D. Liotta and A. Brogi, "Pliocene-Quaternary fault kinematics in the Larderello geothermal area (Italy): insights for the interpretation of the present stress field," Geothermics, vol. 83, article 101714, 2020.

[69] D. Liotta, "The Arbia-Val Marecchia line, northern Apennines," Eclogae Geologicae Helvetiae, vol. 84, pp. 413-430, 1991.

[70] V. Pascucci, I. P. Martini, M. Sagri, and F. Sandrelli, "Effects of transverse structural lineaments on the Neogene-quaternary basins of Tuscany (inner Northern Apennines, Italy)," in Sedimentary processes, environments and basins: a tribute to Peter Friend, G. Nichols, E. Williams, and C. Paola, Eds., vol. 38, pp. 155-182, Intern. Ass. Sediment., Spec. Publ, 2007.

[71] V. Acocella and R. Funiciello, "Transverse structures and volcanic activity along the Tyrrhenian margin of Central Italy," Bollettino della Societa Geologica Italiana, vol. 1, pp. 739747, 2002.

[72] V. Acocella and R. Funiciello, "Transverse systems along the extensional Tyrrhenian margin of Central Italy and their influence on volcanism," Tectonics, vol. 25, no. 2, 2006.

[73] A. Dini, G. Gianelli, M. Puxeddu, and G. Ruggieri, "Origin and evolution of Pliocene-Pleistocene granites from the Lar- derello geothermal field (Tuscan Magmatic Province, Italy)," Lithos, vol. 81, no. 1-4, pp. 1-31, 2005.

[74] A. Dini, D. S. Westerman, F. Innocenti, and S. Rocchi, "Magma emplacement in a transfer zone: the Miocene mafic Orano dyke swarm of Elba Island, Tuscany, Italy," Geological Society of London, Special Publication, vol. 302, no. 1, pp. 131-148, 2008.

[75] D. Liotta, A. Brogi, M. Meccheri, A. Dini, C. Bianco, and G. Ruggieri, "Coexistence of low-angle normal and highangle strike- to oblique-slip faults during Late Miocene mineralization in eastern Elba Island (Italy)," Tectonophysics, vol. 660, pp. 17-34, 2015.

[76] A. Brogi, E. Capezzuoli, I. Martini, M. Picozzi, and F. Sandrelli, "Late Quaternary tectonics in the inner northern Apennines (Siena Basin, southern Tuscany, Italy) and their seismotectonic implication," Journal of Geodynamics, vol. 76, pp. 25-45, 2014.

[77] G. Vignaroli, A. Pinton, A. A. De Benedetti et al., "Structural compartmentalisation of a geothermal system, the Torre Alfina field (Central Italy)," Tectonophysics, vol. 608, pp. 482-498, 2013.

[78] M. Zucchi, "Faults controlling geothermal fluid flow in low permeability rock volumes: an example from the exhumed geothermal system of eastern Elba Island (Northern Tyrrhenian Sea, Italy)," Geothermics, vol. 85, article 101765, 2020.

[79] F. Barberi, "I porfiroidi della Toscana e la loro posizione stratigrafica," Atti del Symposium sul Verrucano. Società Toscana di Scienze Naturali, vol. 34, 1966.

[80] A. Costantini, F. M. Elter, E. Pandeli, and F. Sandrelli, "Geologia dell'area di Iano (Toscana Meridionale, Italia)," Bollettino della Società Geologica Italiana, vol. 117, pp. 187-219, 1998.

[81] K. Bergmann, H. Theuer, and B. W. Shore, "Coherent population transfer among quantum states of atoms and molecules," Reviews of Modern Physics, vol. 70, no. 3, pp. 1003 $1025,1998$.

[82] C. Spötl and T. W. Vennemann, "Continuous-flow isotope ratio mass spectrometric analysis of carbonate minerals," Rapid Communications in Mass Spectrometry, vol. 17, no. 9, pp. 1004-1006, 2003.

[83] J. M. Eiler, ""Clumped-isotope" geochemistry-The study of naturally-occurring, multiply- substituted isotopologues," Earth and Planetary Science Letters, vol. 262, no. 3-4, pp. 309-327, 2007.

[84] P. Ghosh, J. Adkins, H. Affek et al., ${ }^{~}{ }^{13} \mathrm{C}-{ }^{18} \mathrm{O}$ bonds in carbonate minerals: A new kind of paleothermometer," Geochimica et Cosmochimica Acta, vol. 70, no. 6, pp. 1439-1456, 2006.

[85] K. W. Huntington, J. M. Eiler, H. Affek et al., "Methods and limitations of 'clumped' CO2isotope $(\Delta 47)$ analysis by gassource isotope ratio mass spectrometry," Journal of Mass Spectrometry, vol. 44, no. 9, pp. 1318-1329, 2009.

[86] L. Burgener, K. W. Huntington, G. D. Hoke et al., "Variations in soil carbonate formation and seasonal bias over $>4 \mathrm{~km}$ of relief in the western Andes $\left(30^{\circ} \mathrm{S}\right)$ revealed by clumped isotope thermometry," Earth and Planetary Science Letters, vol. 441, pp. 188-199, 2016.

[87] A. J. Schauer, J. Kelson, C. Saenger, and K. W. Huntington, "Choice of ${ }^{17} \mathrm{O}$ correction affects clumped isotope $(\Delta 47)$ values of $\mathrm{CO}_{2}$ measured with mass spectrometry," Rapid Communications in Mass Spectrometry, vol. 30, no. 24, pp. 2607-2616, 2016. 
[88] W. A. Brand, S. S. Assonov, and T. B. Coplen, "Correction for the ${ }^{17} \mathrm{O}$ interference in $\delta\left({ }^{13} \mathrm{C}\right)$ measurements when analyzing $\mathrm{CO}_{2}$ with stable isotope mass spectrometry (IUPAC technical report)," Pure and Applied Chemistry, vol. 82, no. 8, pp. 1719-1733, 2010.

[89] B. He, G. A. Olack, and A. S. Colman, "Pressure baseline correction and high-precision $\mathrm{CO} 2$ clumped-isotope $(\Delta 47)$ measurements in bellows and micro-volume modes," Rapid Communications in Mass Spectrometry, vol. 26, no. 24, pp. 2837-2853, 2012.

[90] S. M. Bernasconi, I. A. Müller, K. D. Bergmann et al., "Reducing uncertainties in carbonate clumped isotope analysis through consistent carbonate-based standardization," Geochemistry, Geophysics, Geosystems, vol. 19, no. 9, pp. 28952914, 2018.

[91] S. V. Petersen, W. F. Defliese, C. Saenger et al., "Effects of Improved ${ }^{17} \mathrm{O}$ correction on interlaboratory agreement in clumped isotope calibrations, estimates of mineral-specific offsets, and temperature dependence of acid digestion fractionation," Geochemistry, Geophysics, Geosystems, vol. 20, no. 7, pp. 3495-3519, 2019.

[92] S. Kele, S. F. M. Breitenbach, E. Capezzuoli et al., "Temperature dependence of oxygen- and clumped isotope fractionation in carbonates: A study of travertines and tufas in the 6-95 ${ }^{\circ} \mathrm{C}$ temperature range," Geochimica et Cosmochimica Acta, vol. 168, pp. 172-192, 2015.

[93] J. R. Kelson, K. W. Huntington, A. J. Schauer, C. Saenger, and A. R. Lechler, "Toward a universal carbonate clumped isotope calibration: diverse synthesis and preparatory methods suggest a single temperature relationship," Geochimica et Cosmochimica Acta, vol. 197, pp. 104-131, 2017.

[94] C. M. John and D. Bowen, "Community software for challenging isotope analysis: first applications of 'Easotope' to clumped isotopes," Geochemistry, Geophysics, Geosystems, vol. 30, no. 21, pp. 2285-2300, 2016.

[95] C.-C. Shen, C.-C. Wu, H. Cheng et al., "High-precision and high-resolution carbonate ${ }^{230}$ Th dating by MC-ICP-MS with SEM protocols," Geochimica et Cosmochimica Acta, vol. 99, pp. 71-86, 2012.

[96] C.-C. Shen, H. Cheng, R. L. Edwards et al., "Measurement of attogram quantities of ${ }^{231} \mathrm{~Pa}$ in dissolved and particulate fractions of seawater by isotope dilution thermal ionization mass spectroscopy," Analytical Chemistry, vol. 75, no. 5, pp. 10751079, 2003.

[97] C.-C. Shen R. L. Edwards et al., "Uranium and thorium concentration measurements by magnetic sector inductively coupled plasma mass spectrometry," Chemical Geology, vol. 155, pp. 165-178, 2002.

[98] H. Cheng, R. Lawrence Edwards, C.-C. Shen et al., "Improvements in ${ }^{230}$ Th dating, ${ }^{230} \mathrm{Th}$ and ${ }^{234} \mathrm{U}$ half-life values, and $\mathrm{U}$ Th isotopic measurements by multi-collector inductively coupled plasma mass spectrometry," Earth and Planetary Science Letters, vol. 371-372, pp. 82-91, 2013.

[99] E. Cortese, Due particolarità geologiche presso Iano, Boll. Soc. Geolog. It, L, Roma, 1931.

[100] R. Masini, "I tre sondaggi sul permocarbonifero della catena metallifera," Atti della Società Toscana di Scienze Naturali, Serie A, vol. 67, pp. 57-80, 1960.

[101] E. Capezzuoli, A. Gandin, and M. Pedley, "Decoding tufa and travertine (fresh water carbonates) in the sedimentary record: the state of the art," Sedimentology, vol. 61, no. 1, pp. 1-21, 2013.
[102] R. Celati, S. Grassi, and C. Calore, "Overflow thermal springs of Tuscany (Italy)," Journal of Hydrology, vol. 118, no. 1-4, pp. 191-207, 1990.

[103] H. S. Chafetz and S. A. Guidry, "Bacterial shrubs, crystal shrubs, and ray-crystal shrubs: bacterial vs. abiotic precipitation," Sedimentary Geology, vol. 126, no. 1-4, pp. 57-74, 1999.

[104] M. M. Erthal, E. Capezzuoli, A. Mancini, H. Claes, J. Soete, and R. Swennen, "Shrub morpho-types as indicator for the water flow energy - Tivoli travertine case (Central Italy)," Sedimentary Geology, vol. 347, pp. 79-99, 2017.

[105] S. Vettori, E. Cantisani, L. Chelazzi, O. A. Cuzman, G. D. Gatta, and F. D'Andria, "The dark colour of thePloutonionat Hierapolis of Phrygiae (Turkey)," Archaeometry, vol. 61, no. 2, pp. 296-308, 2018.

[106] S. M. Antao and I. Hassan, "The orthorhombic structure of $\mathrm{CaCO}_{3}, \mathrm{SrCO}_{3}, \mathrm{PbCO}_{3}$ and $\mathrm{BaCO}_{3}$ : linear structural trends," The Canadian Mineralogist, vol. 47, no. 5, pp. 1245-1255, 2009.

[107] G. Falini, S. Fermani, M. Gazzano, and A. Ripamonti, "Oriented Crystallization of Vaterite in Collagenous Matrices," Chemistry A European Journal, vol. 4, no. 6, pp. 1048-1052, 1998.

[108] R. J. Reeder, G. M. Lamble, and P. A. Northrup, "XAFS study of the coordination and local relaxation around $\mathrm{Co}\left(\right.$ super $\left.^{2+}\right)$, $\mathrm{Zn}\left(\right.$ super $\left.^{2+}\right), \mathrm{Pb}\left(\right.$ super $\left.^{2+}\right)$, and $\mathrm{Ba}\left(\right.$ super $\left.^{2+}\right)$ trace elements in calcite," American Mineralogist, vol. 84, no. 7-8, pp. 10491060, 1999.

[109] S. Bernardini, F. Bellatreccia, A. Casanova Municchia, G. Della Ventura, and A. Sodo, "Raman spectra of natural manganese oxides," Journal of Raman Spectroscopy, vol. 50, pp. 873-888, 2019.

[110] S. Frisia, "Microstratigraphic logging of calcite fabrics in speleothems as tool for palaeoclimate studies," International Journal of Speleology, vol. 44, no. 1, pp. 1-16, 2015.

[111] P. Romagnoli, A. Arias, A. Barelli, M. Cei, and M. Casini, "An updated numerical model of the Larderello-Travale geothermal system, Italy," Geothermics, vol. 39, no. 4, pp. 292-313, 2010.

[112] S. Bellani, A. Brogi, A. Lazzarotto, D. Liotta, and G. Ranalli, "Heat flow, deep temperatures and extensional structures in the Larderello Geothermal Field (Italy): constraints on geothermal fluid flow," Journal of Volcanology and Geothermal Research, vol. 132, no. 1, pp. 15-29, 2004.

[113] G. Magro, G. Ruggieri, G. Gianelli, S. Bellani, and G. Scandiffio, "Helium isotopes in paleofluids and presentday fluids of the Larderello geothermal field: constraints on the heat source," Journal of Geophysical Research: Solid Earth, vol. 108, no. B1, pp. ECV 3-1-ECV 3-12, 2003.

[114] G. Magro, S. Bellani, and B. Della Vedova, “The deep roots of the Larderello geothermal field (Italy) from heat flux and $3 \mathrm{He}$ anomalies," GRC Transactions, vol. 33, 2009.

[115] A. Minissale, O. Vaselli, F. Tassi, G. Magro, and G. P. Grechi, "Fluid mixing in carbonate aquifers near Rapolano (Central Italy): chemical and isotopic constraints," Applied Geochemistry, vol. 17, no. 10, pp. 1329-1342, 2002.

[116] L. Marini and G. Chiodini, "The role of $\mathrm{CO}_{2}$ in the carbonateevaporite geothermal systems of Tuscany and Latium, Italy," Acta Vulcanologica, vol. 5, pp. 95-104, 1994.

[117] A. Minissale, "Thermal springs in Italy: their relation to recent tectonics," Applied Geochemistry, vol. 6, no. 2, pp. 201-212, 1991. 
[118] C. Panichi and E. Tongiorgi, "Carbon isotopic composition of $\mathrm{CO} 2$ from springs, fumaroles, mofettes and travertines of central and southern Italy: a preliminary prospection method of geothermal areas," in Proceedings 2nd U.N. Symposium on the Development and Use of Geothermal Energy, pp. 815-825, San Francisco, USA, 1976.

[119] G. Gianelli, "On the origin of geothermal $\mathrm{CO}_{2}$ by metamorphic processes," Bollettino della Societa Geologica Italiana, vol. 104, pp. 575-584, 1985.

[120] M. Javoy, F. Pineau, and C. J. Allegre, "Carbon geodynamic cycle," Nature, vol. 300, no. 5888, pp. 171-173, 1982.

[121] G. Faure, Principles of Isotope Geology, J. Wiley, New York, 1977.

[122] T. E. Cerling, D. K. Solomon, J. Quade, and J. R. Bowman, "On the isotopic composition of carbon in soil carbon dioxide," Geochimica et Cosmochimica Acta, vol. 55, no. 11, pp. 3403-3405, 1991.

[123] H. Rollinson, Using Geochemical Data, Longman Group, London, 1993.

[124] A. Minissale, W. C. Evans, G. Magro, and O. Vaselli, "Multiple source components in gas manifestations from northcentral Italy," Chemical Geology, vol. 142, no. 3-4, pp. 175192, 1997.

[125] V. Duchi, M. V. Giordano, and M. Martini, "Riesame del problema della precipitazione di calcite od aragonite da soluzioni naturali," Rendiconti della Società Italiana di Mineralogia e Petrologi, vol. 34, no. 2, pp. 605-618, 1978.

[126] S.-T. Kim, J. R. O’Neil, C. Hillaire-Marcel, and A. Mucci, "Oxygen isotope fractionation between synthetic aragonite and water: Influence of temperature and $\mathrm{Mg}^{2+}$ concentration," Geochimica et Cosmochimica Acta, vol. 71, no. 19, pp. 4704-4715, 2007.

[127] T. Chacko and P. Deines, "Theoretical calculation of oxygen isotope fractionation factors in carbonate systems," Geochimica et Cosmochimica Acta, vol. 72, no. 15, pp. 3642-3660, 2008.

[128] E. Petrucci, S. M. F. Sheppard, and B. Turi, "Water/rock interaction in the Larderello geothermal field (southern Tuscany, Italy): an ${ }^{18} \mathrm{O}^{16} \mathrm{O}$ and $\mathrm{DH}$ isotope study," Journal of Volcanology and Geothermal Research, vol. 59, no. 1-2, pp. 145-160, 1993.

[129] G. Cortecci and L. Lupi, "Carbon, oxygen and strontium isotope geochemistry of carbonate rocks from the Tuscan nappe," Mineralogica et Petrographica Acta, vol. 27, pp. 6380, 1994.

[130] R. H. Sibson, "Fluid involvement in normal faulting," Journal of Geodynamics, vol. 29, no. 3-5, pp. 469-499, 2000.

[131] E. Olvera-García, V. H. Garduño-Monroy, D. Liotta, A. Brogi, G. Bermejo-Santoyo, and J. A. Guevara-Alday, "Neogene-Quaternary normal and transfer faults controlling deep-seated geothermal systems: the case of San Agustin del Maiz (central Trans-Mexican Volcanic Belt, Mexico)," Geothermics, vol. 86, article 101791, 2020.

[132] P. Pérez-Flores, E. Veloso, J. Cembrano, P. Sanchez-Alfaro, M. Martin Lizama, and G. Arancibia, "Fracture network, fluid pathways and paleostress at the Tolhuaca geothermal field," Journal of Structural Geology, vol. 96, pp. 134-148, 2017.

[133] Á. Török, H. Claes, A. Brogi et al., "A multi-methodological approach to reconstruct the configuration of a travertine fissure ridge system: the case of the Cukor quarry (Suttö, Gerecse Hills, Hungary)," Geomorphology, vol. 345, article 106836, 2019.
[134] A. Brogi, "Fault zone architecture and permeability features in siliceous sedimentary rocks: insights from the Rapolano geothermal area (northern Apennines, Italy)," Journal of Structural Geology, vol. 30, no. 2, pp. 237-256, 2008.

[135] A. Brogi and L. Fabbrini, "Extensional and strike-slip tectonics across the Monte Amiata-Monte Cetona transect (northern Apennines, Italy) and seismotectonic implications," Tectonophysics, vol. 476, pp. 195-209, 2009.

[136] A. Brogi, M. C. Alçiçek, D. Liotta, E. Capezzuoli, M. Zucchi, and P. F. Matera, "Step-over fault zones controlling geothermal fluid-flow and travertine formation (Denizli Basin, Turkey)," Geothermics, vol. 89, article 101941, 2021.

[137] V. Rimondi, P. Costagliola, G. Ruggieri et al., "Investigating fossil hydrothermal systems by means of fluid inclusions and stable isotopes in banded travertine: an example from Castelnuovo dell'Abate (southern Tuscany, Italy)," International Journal of Earth Sciences, vol. 105, no. 2, pp. 659-679, 2016.

[138] G. Vignaroli, G. Berardi, A. Billi et al., "Tectonics, hydrothermalism, and paleoclimate recorded by quaternary travertines and their spatio-temporal distribution in the Albegna basin, Central Italy: insights on Tyrrhenian margin neotectonics," Lithosphere, vol. 8, no. 4, pp. 335-358, 2016.

[139] A. Brogi, E. Capezzuoli, M. Moretti et al., "Earthquake-triggered soft-sediment deformation structures (seismites) in travertine deposits," Tectonophysics, vol. 745, pp. 349-365, 2018.

[140] U. Temiz, E. Gökten, and J. Eikenberg, "U/Th dating of fissure ridge travertines from the Kirsehir region (Central Anatolia Turkey): structural relations and implications for the Neotectonic development of the Anatolian block," Geodinamica Acta, vol. 22, no. 4, pp. 201-213, 2012.

[141] U. Temiz, Y. E. Gökten, and J. Eikenberg, "Strike-slip deformation and U/Th dating of travertine deposition: examples from North Anatolian Fault Zone, Bolu and Yeniçağ Basins, Turkey," Quaternary International, vol. 312, pp. 132-140, 2013.

[142] E. Ünal-İmer, I. U. Uysal, J. Zhao et al., “ $\mathrm{CO}_{2}$ outburst events in relation to seismicity: constraints from microscale geochronology, geochemistry of late Quaternary vein carbonates, SW Turkey," Geochimica et Cosmochimica Acta, vol. 187, pp. 21-40, 2016.

[143] A. Mancini, F. Frondini, E. Capezzuoli et al., "Evaluating the geogenic $\mathrm{CO}_{2}$ flux from geothermal areas by analysing quaternary travertine masses. New data from western Central Italy and review of previous $\mathrm{CO}_{2}$ flux data," Quaternary Science Reviews, vol. 215, pp. 132-143, 2019.

[144] A. Brogi, E. Capezzuoli, S. Kele, M. O. Baykara, and C.C. Shen, "Key travertine tectofacies for neotectonics and palaeoseismicity reconstruction: effects of hydrothermal overpressured fluid injection," Journal of the Geological Society, vol. 174, no. 4, pp. 679-699, 2017.

[145] R. L. Folk, "Interaction between bacteria, nannobacteria, and mineral precipitation in hot springs of central Italy," Géographie physique et Quaternaire, vol. 48, no. 3, pp. 233-246, 1994.

[146] B. W. Fouke, J. D. Farmer, D. J. Des Marais et al., "Depositional facies and aqueous-solid geochemistry of travertine depositing hot springs (Angel Terrace, Mammoth Hot Springs, Yellowstone National Park, U.S.A.)," Journal of Sedimentary Research, vol. 70, no. 3, pp. 565-585, 2000.

[147] F. Lippmann, Sedimentary Carbonate Minerals, SpringerVerlag, Heidelberg, 1973. 
[148] D. Flinn and A. Pentecost, "Travertine-cemented screes on the serpentinite seacliffs of Unst and Fetlar, Shetland," Mineralogical Magazine, vol. 59, no. 395, pp. 259-265, 1995.

[149] F. Lippmann, "Verfuche z.ur Aulk!iirung der Bildengsbedingungen von $\mathrm{Ca} / \mathrm{ciI}$ und Aragonil," Fortschritte dct Mineralogie, vol. 38, pp. 156-161, 1960.

[150] P. Malesani and S. Vannucchi, "Precipitazione di calcite o di aragonite dalle acque termominerale in relazione alla genesi e all'evoluzione dei travertini," Atti della R. Accademia d'Italia, vol. 58, pp. 761-776, 1975.

[151] I. Sunagawa, Y. Takahashi, and H. Imai, "Strontium and aragonite-calcite precipitation," Journal of Mineralogical and Petrological Sciences, vol. 102, no. 3, pp. 174-181, 2007.

[152] N. Kampman, N. M. Burnside, Z. K. Shipton et al., "Pulses of carbon dioxide emissions from intracrustal faults following climatic warming," Nature Geoscience, vol. 5, no. 5, pp. 352-358, 2012.

[153] G. Sürmelihindi, C. Passchier, C. Spötl et al., "Laminated carbonate deposits in Roman aqueducts: origin, processes and implications," Sedimentology, vol. 60, no. 4, pp. 961-982, 2013.

[154] R. Gonfiantini, C. Panichi, and E. Tongiorgi, "Isotopic disequilibrium in travertine deposition," Earth and Planetary Science Letters, vol. 5, pp. 55-58, 1968.

[155] I. Friedman, "Some investigations of the deposition of travertine from hot-springs-I. the isotopic chemistry of a travertine depositing spring," Geochimica et Cosmochimica Acta, vol. 34, no. 12, pp. 1303-1315, 1970.

[156] S. Kele, A. Demény, Z. Siklósy, T. Németh, M. Tóth, and M. B. Kovács, "Chemical and stable isotope composition of recent hot-water travertines and associated thermal waters, from Egerszalok, Hungary: depositional facies and nonequilibrium fractionation," Sedimentary Geology, vol. 211, no. 3-4, pp. 53-72, 2008.

[157] C. G. Koban and G. Schweigert, "Microbial origin of travertine fabrics-two examples from southern Germany (Pleistocene Stuttgart travertines and Miocene riedöschingen travertine)," Facies, vol. 29, no. 1, pp. 251-263, 1993.

[158] W. E. Krumbein and K. Jens, "Biogenic rock varnishes of the Negev desert (Israel) an ecological study of iron and manganese transformation by cyanobacteria and fungi," Oecologia, vol. 50, no. 1, pp. 25-38, 1981.

[159] B. Jones, "Void-filling deposits in karst terrains of isolated oceanic islands: a case study from tertiary carbonates of the Cayman Islands," Sedimentology, vol. 39, no. 5, pp. 857876, 1992.

[160] K. Rankama and T. G. Sahama, Geochemistry, University of Chicago Press, Chicago, 1960.

[161] B. M. Tebo, J. R. Bargar, B. G. Clement et al., "Biogenic manganese oxides: properties and Mechanisms of formation," Annual Review of Earth and Planetary Sciences, vol. 32, no. 1, pp. 287-328, 2004. 